\title{
Urbanization as Socioenvironmental Succession: The Case of Hazardous Industrial Site Accumulation ${ }^{1}$
}

\author{
James R. Elliott \\ Rice University \\ Scott Frickel \\ Brown University
}

\begin{abstract}
This study rehabilitates concepts from classical human ecology and synthesizes them with contemporary urban and environmental sociology to advance a theory of urbanization as socioenvironmental succession. The theory illuminates how social and biophysical phenomena interact endogenously at the local level to situate urban land use patterns recursively and reciprocally in place. To demonstrate this theory we conduct a historical-comparative analysis of hazardous industrial site accumulation in four U.S. cities, using a relational database that was assembled for more than 11,000 facilities that operated during the past half century - most of which remain unacknowledged in government reports. Results show how three iterative processes-hazardous industrial churning, residential churning, and risk containment - intersect to produce successive socioenvironmental changes that are highly relevant to but often missed by research on urban growth machines, environmental inequality, and systemic risk.
\end{abstract}

Visible from outer space, voracious consumers of energy and resources, and home to more than half the world's human population, cities are arguably

\footnotetext{
${ }^{1}$ We thank Matt Clement, Ali Ilhan, Mark Leymon, Jessica Schultz, and Eric Stipe for invaluable research assistance. The $A J S$ referees provided incisive feedback that improved the study in many ways. This research benefited from collaborative funding

(C) 2015 by The University of Chicago. All rights reserved. 0002-9602/2015/12006-0004\$10.00
} 
the most environmentally significant form of social organization. Public debates rage over whether they hold the keys to building sustainable societies or represent major impediments to achieving renewable futures (Fitzgerald 2010; Peter and Swilling 2012). Either way, it remains clear that cities are manifestations of complex and ongoing interactions between the natural and social world and as such represent laboratories of possibilities for forging a more comprehensive theory of socioenvironmental forms.

This article argues that cities - central subjects of classical sociological analysis - are fundamentally outcomes of cyclical socioenvironmental change and that urbanization provides the lens through which to study these processes historically and comparatively. Further, we contend that key conceptual building blocks for developing such an environmental sociology of cities have been at hand for nearly a century, hiding in plain sight within the theoretical armature of the early Chicago school's program in human ecology and its conceptual focus on "ecological succession" and "natural areas" (McKenzie 1925; Park 1936). From these basic and in some ways outmoded concepts, we pursue a repurposed and extended theory of socioenvironmental succession to describe endogenous dynamics of urbanization and to identify local mechanisms that drive the reciprocal and iterative intertwining of society and nature.

The framework we develop parallels macrohistorical perspectives in political ecology (e.g., Bunker 1984; Foster 1999; Moore 2000). But, rather than emphasize how capitalism's dual exploitation of nature and labor creates a "metabolic rift" between city and countryside by depleting the latter and polluting the former, we enter the city to examine how and why hazardous industrial sites accumulate to contaminate urban lands. "Going local" in this way shifts attention from macrointeractions of urban and exogenous rural environments to mesolevel endogenous processes of recursive redevelopment and reuse of city grounds, which offers several contributions: It historicizes urban growth machines to emphasize their iterative interaction with local environments (Molotch 1976; Logan and Molotch 1987). It recovers forgotten sources of manufactured risk (Beck 1992, 2009) and environmental inequality (Crowder and Downey 2010). And it advances efforts to develop a conceptually richer political ecology of place (e.g., Tarr 2002; Melosi 2010; Brenner 2013).

Below we develop this framework, first situating our theory within the context of classical human ecology and contemporary urban and environmental sociology. We then demonstrate the empirical utility of this theory through historically comparative analysis of a unique relational database

from the National Science Foundation (awards SES-0849826 and SES-0849823). Direct correspondence to James Elliott, Department of Sociology MS-28, Rice University, Houston, Texas 77005. E-mail: james.r.elliott@rice.edu 
containing information on more than 11,000 hazardous industrial sites that have accumulated in four U.S. cities during the past half century. Results show how urbanization is a dynamic, spatially situated process of socioenvironmental succession in which relatively undramatic site-level processes scale up to produce cumulatively significant socioenvironmental change.

\section{ECOLOGICAL SUCCESSION AND NATURAL AREAS OF THE CHICAGO SCHOOL}

In his classic 1936 article on ecological succession, Robert Park explains how sociologists should modify plant and animal ecology to study human society. He begins by proposing that "human society is . . organized on two levels, the biotic and the cultural," each of which "imposes limits, control, and direction upon ... individual units" (1936, pp. 175, 176). He also explains that each of these levels unfolds on itself in successive fashion, such that "the effect of each increment of change reinforces or carries forward the effects of the preceding" (p. 177). Park then makes two important paradigm-altering moves. He drops plant and animal ecology's focus on the biotic while simultaneously amplifying its focus on the territorial. The result is a spatially contextualized understanding of social life in which the goal is "less to predict the course of change than to make change intelligible" (Park 1936, p. 178). As such, Park explains that "studies of succession are concerned not only with the form which change takes but even more with the circumstances and events which precede, accompany and follow change-in short, with its natural history" (Park 1936, p. 178).

Park and colleagues go on to explain that in order to develop a natural history of social change sociologists must study natural areas, which they conceptualize as natural not in any ecological sense but rather in the sense that they are unplanned and irreversible manifestations, or residues, of more encompassing and ongoing processes of urban territorial succession. Within this dynamic context, such areas - say, a Jewish ghetto (Wirth 1928) or hobo "main stem" (Anderson 1923) — are understood to be emergent, cultural products of history's interaction with the territories, or social spaces, that humans create and that become rooted, or "located," in time and space, "surrounded by other [contexts] and brought into being by a process relating it to past contexts" (Abbott 1999, p. 197). So over time, even as cities expand spatially by bringing newly annexed land under development (Bullard, Johnson, and Torres 2000; Rudel, Roberts, and Carmin 2011), urbanization comes to operate increasingly as an endogenous process of serial change taking place in and among historically produced natural areas. These natural areas in turn scale up to produce a "cultural super-structure" that can "impose limits, control and direction" on local inhabitants as well as on the larger urban area in which they are embedded (Park 1925, p. 60). 
In early applications of this framework, human ecologists not only studied social life and spatial patterns in and among respective natural areas but also highlighted the role of local institutions in regulating and accelerating the broader process of territorial succession of which they were a part. Hoyt's (1933) study of the Chicago Real Estate Board, for example, emphasized the role that this emergent association played in regulating local lands culturally so that they could be used and reused at great profit over successive generations of owners and occupants. These accomplishments encouraged real estate boards and related institutions in Chicago and elsewhere to form local progrowth coalitions, or "growth machines" (Molotch 1976), that could wield powerful tools to steer city government toward policies and programs that further intensified local land reuse. ${ }^{2}$ These policies and programs, in turn, allowed local land-based elites and their allies in city hall to extract higher rents from privatized lots, thereby expanding their ability to control and develop urban land as a form of fixed capital assets, which over time helped them to concentrate political power and extend economic influence over local urbanization processes.

In these ways, sociologists retained a central idea from early plant ecologists that ecological succession involved "directional" changes that "gradually transform the environment" (cf. Rudel 2013, p. 13). But they adapted this idea to make much narrower reference to social processes interacting with social space-cum-natural areas-broadly excluding interaction with the biophysical landscapes and ecosystems where such processes play out. Indeed and in contrast to classic plant and animal ecology (Clements 1916), the human ecology of the Chicago school came to treat environmental phenomena as given, immutable, and uninteresting. With this shift, urban ecosystems represented variegated but timeless topographies. River banks, hillsides, and floodplains became backdrops for urban cultural processes of territorial succession. As a result, early architects of the Chicago school failed to fully appreciate how the distinctly cultural processes of succession they studied - which involved initial settlement, serial resettlement, and political coalition building - reciprocally interacted with and transformed local environments with which they remained inextricably connected (Gross 2004). They also ignored how these connections conditioned competition for land use and subsequent transformation of urban populations.

Several subsequent shifts undertaken by Chicago sociologists and their students reinforced this less environmentally attentive conceptualization of succession. One shift was from broad usage of the term to connote serial territorial change of any type (as described by Park in 1936) to far narrower

${ }^{2}$ These tools include public transfers for infrastructural improvements, zoning laws, planning boards, and, more recently, environmental regulations designed to manage financial and public health risk from industrial wastes (Rudel 1989). 
usage to connote residential "invasion" of specific neighborhoods by new subpopulations. ${ }^{3}$ With this shift, the once inclusive concept of ecological succession often came to signify little more than an outcome, or end result, of movements of different groups in and through various zones of the city over time (Hawley 1944). This conceptual contraction was further reinforced by an analytical shift from explanation to description, as researchers tapered their goal from understanding urban (social) systems as a whole to describing activities in constituent natural areas. ${ }^{4}$ Consequently, the more human ecology developed at Chicago and elsewhere, the less theoretical it became (Matthews 1977; Burns 1980). And, the less theoretical it became, the more resolutely it focused on residential turnover in and between cultural and economic spaces rather than on changes that such turnover successively produces in the broader urban-ecological system. The Chicago school's program for a human ecology of cities thus drifted slowly into abeyance, such that by the 1950s it no longer dominated the field or invited serious critique (Freudenberg 1985; Maines, Bridges, and Ulmer 1996; Abbott 1999; Rudel 2009; see also Gaziano 1996).

Despite these developments, with Rudel (2013) we contend that classic concepts of ecological succession and natural areas still hold great promise for making theoretical sense of urbanization as a fundamentally socioenvironmental process. Developing this promise requires shifting focus from strictly cultural phenomena to what Molotch (1976, p. 309) calls "the basic stuff of place"- the land - to develop a broader theory of socioenvironmental change.

\section{SOCIOENVIRONMENTAL SUCCESSION IN THE 20TH CENTURY AND BEYOND}

We define socioenvironmental succession to mean interactions among social and biophysical phenomena that situate urban land use patterns recursively and reciprocally in place. The aim is to reestablish complex entwinements of social and natural worlds that are rendered invisible in human ecology by Park's partitioning of urban culture from urban ecosystems. These entwinements involve not just spatial division and privatization of urban lots that comprise natural areas that Chicago sociologists

\footnotetext{
${ }^{3}$ In taking a broad view of territorial succession, Park's theory ran parallel to Clements (1916), whose original treatment of ecological succession identified six distinct causesnone of which he named "invasion" (see Pickett, Cadenasso, and Meiners 2008).

${ }^{4}$ By 1944, Amos Hawley would define human ecology as, "the descriptive study of the adjustment of human populations to the conditions of their respective physical environments" (p. 404; see also Hawley 1986).
} 
studied (cf. Burgess 1926) but also the continual redevelopment and reuse of urban space as a whole (Elliott and Frickel 2013). Over time, this recursive dynamic produces a change in forms of (continually reproduced) urban organization that is neither strictly social nor strictly environmental but instead deeply and mutually constitutive of both.

Examples of such socioenvironmental succession include highly visible topographical and infrastructural changes to local areas in the form of roads, bridges, and canals, which have garnered significant scholarly attention as forms of "second nature" (Cronon 1991). But they also include less visible but equally important biological, chemical, and geophysical changes in lands themselves. These changes can include soil compaction and subsidence, nutrient depletion, chemical additions and transport, or changes in the level or flow of subsurface waters - types of socioenvironmental succession that shift analytical focus toward unintentional and often unrecorded changes wrought by ongoing urban development. Like Park's cultural processes of succession, these socioenvironmental processes contextually locate themselves in and reflect particular places and times. Thus, we can discern urban-scale variations across different historical periods, which accumulate successively to reshape urban areas and constituent natural areas.

In the United States during the 18th and 19th centuries, these processes of socioenvironmental succession were most evident in long-term, largescale capital- and labor-intensive projects that dramatically and lastingly transformed urban landscapes. Famous examples include the flattening of hills and subsequent filling in of tidal marshes to create Boston's Back Bay (Meyer 2009) and the reversing of a major waterway to develop Chicago's lakefront (Cronon 1991). Such dramatic changes to urban landscapes continued throughout the 20th century, as when developers drained and graded the marshes of New Orleans' "back-a-town" areas for residential development in the 1950s (Kelman 2006) and when Los Angeles developers paved over once visible evidence of seismic faults running throughout the metropolitan area, inadvertently hiding data critical to earthquake-modeling experts and emergency management professionals (Davis 1999).

Yet, even as these highly visible landscape transformations continue, a less visible but more pervasive form of transformation came to characterize socioecological succession in the 20th century and beyond: changes wrought by the industrialization of cities and subsequent contamination of urban lands by hazardous wastes. To be sure, there are historical precedents here too: Paris now ranks as one of France's largest lead mines as a result of successive accumulations of the metal since Roman antiquity (Lestel, Meybeck, and Thévenot 2007; Barles 2010), and Stockholm now suffers from widespread mercury contamination that has accumulated in 
local soils for more than two centuries from the manufacture of "felt hats, mirrors and thermometers; techniques for gilding and silvering and, especially, treatments for syphilis and dental cavities" (Barles 2010, p. 449; cf. Sveden and Jonsson 2001). These older historical cases reflect and embody the mutual constitution of nature and society through successive and ongoing interactions in which hazardous substances are "converted, used and incorporated into the urban environment" (Barles 2010, p. 449). After the 1930s, however, these processes qualitatively changed to include "a new spectrum of wastes whose quantities, toxicity, and [ecological] persistence took quantum leaps" in the United States and elsewhere (Colten and Skinner 1996, p. 5), making this form of socioenvironmental succession increasingly pronounced, as well as politically and environmentally complex.

During this more recent period, industrially manufactured chemical contaminants have found their way into urban soils at exponentially greater scales, rates, and volumes than ever before (Hays 1987), while many of the regulations subsequently crafted to address these developments have unintentionally complicated and even exacerbated the problem (Hawkins 1984). As a result, the gradual but relentless transformation of urban lands by industrial wastes - pound by pound, parcel by parcel, year after year-has become cumulatively significant. And as this crescive degradation of urban lands occurs, it produces new and uneven "landscapes of exposure" (Mitman, Murphy, and Sellers 2004) and with them pervasive and intensifying inequalities between urban residents who are disproportionately burdened by exposure to such environmental threats and others who seem relatively insulated from them (Brulle and Pellow 2006).

We posit that this widespread transformation of urban lands through ongoing accumulation of diverse and large volumes of hazardous industrial waste is a distinctive feature of contemporary urbanization. We also posit that this form of socioenvironmental succession continues to transpire through the intersection of three recursively endogenous processes that produce, distribute, and obscure on-site deposits of hazardous industrial wastes in ways that, when uncovered, begin to reveal a more systemic picture of urban risk.

\section{Hazardous Industrial Churning}

Industrial facilities have long clustered spatially in ways observed by classical human ecology (Hoyt 1939). Historically, growth machines steered this type of development toward areas located just outside central business districts, which afforded factory owners access to railways, waterways, and arterial roads, in addition to nearby banks and business services. In these areas, industrialists built multistory factories, loft warehouses, and row hous- 
ing that now conjoin with ongoing spatial centrality to offer subsequent growth machines attractive opportunities for repurposing existing sites. New kinds of uses include not only nontraditional commercial, civic, and residential enterprises associated with gentrification but also new hazardous manufacturing conducted by small and medium-size establishments that make up a significant share of today's urban industrial base (Mistry and Byron 2011). ${ }^{5}$

In this way, industrial facilities that produce and deposit hazardous waste on-site not only cluster but also shuffle in and out of operation over time so that they occupy - and frequently contaminate-successively larger shares of urban land. Deindustrialization has not halted this churning as much as shifted momentum downward to small and medium-size facilities, which are not only more likely than large establishments to fly below the radar of existing regulations but also to go out of business and convert to other uses without much scrutiny. Such hazardous industrial churning contributes to a central but underappreciated feature of urbanization and is an important mechanism driving contemporary socioenvironmental succession. Through this process, discrete sites of concern accumulate through time to fill in hazardous natural areas that can grow to affect entire urban systems, as exemplified by present-day Detroit (LeDuff 2013). Such hazardous industrial churning has important conceptual and empirical implications.

Conceptually, it adds historical depth to research that invokes urban growth machines to explain local industrial and commercial development (Molotch 1976; Logan and Molotch 1987). Whereas this literature conceptualizes land use contests surrounding such development as contemporaneous struggles between unequal interest groups, our focus on churning of hazardous industry within urban areas draws attention to the historically successive character of these contests, each taking place on land previously altered through prior cycles of struggle and development. This recursive nature of urbanization implies that hazardous natural areas emerge as unintended consequences of a broader, underlying process of socioenvironmental succession. It also recasts particular growth machine contests - say, over the siting of a new hazardous facility - as specific instances of the broader, historical, and ongoing transformation of local lands.

Empirically, hazardous industrial churning also implies that, despite decades of well-intentioned regulation, the accumulation of land-based hazards from industrial sources continues. As described more fully below, industry has responded to air and water regulations imposed over the last

${ }^{5}$ More specifically, since the 1970 s, smaller manufacturers have been gaining increasing shares of the sector such that toward the end of our study period in 2007, $70 \%$ of U.S. manufacturing firms employed fewer than 20 workers (Mistry and Byron 2011, p.13). 
half century by burying more of its hazardous waste on-site. Reports indicate that between 1950 and 1979, chemical manufacturers used land-based disposal methods for $94 \%$ of their hazardous wastes, discarding $80 \%$ to lands on their own production sites (U.S. Congress 1979; see also Dietrich 1981; Page 1997). And this trend persists. A recent study shows that although emissions of hazardous wastes and other toxic releases decreased by $3 \%$ in North America during the late 1990s (largely through reductions in air emissions), disposal of hazardous wastes to land increased by $25 \%$ (Fletcher 2003). Indeed, the latest federal reports indicate that this practice now results in more than 3.6 billion pounds of hazardous waste being dumped into on-site industrial lands each year - a figure that includes only releases voluntarily reported by larger establishments (U.S. Environmental Protection Agency [EPA] 2011).

As these deposits continue to accumulate over time and space through processes of hazardous industrial churning, contaminated soils become increasingly unbound, or systemic (Beck 2009), creating new and vexing problems for urban residents and policy makers and altering rent-seeking opportunities for manufacturers, developers, and other growth machine actors. ${ }^{6}$

\section{Residential Churning}

As hazardous industries churn and cluster to produce hazardous natural areas within cities, residential groups also churn and cluster. Often these demographic processes occur slowly, creating neighborhoods bound not just by shared space but also by shared "sentiments, traditions and a history of [their] own" (Park 1925, 60). Yet over time different groups tend to come and go through what classical human ecology calls "invasion." As this process occurs, new residential groups enter and reuse existing urban spaces, reinventing local institutions, norms, and sense of place. This understanding of residential churning remains central to rich and ongoing research on racial and economic segregation (Reardon and Bischoff 2011;

\footnotetext{
${ }^{6}$ In the present study, environmental or resource rent seeking occurs when individuals, firms, and public interest organizations lobby government for subsidies that give the interested party competitive advantages in developing or redeveloping urban land (e.g., through liability-free investment opportunities) or engage in activities that directly and indirectly keep rents from declining in the face of ongoing environmental degradation. In this approach, growth machines are conceptualized as intensifying and maintaining local land use, which can occur within urban boundaries through filling in and redevelopment as well as through extension of urban boundaries through suburban and exurban development. How and to what extent these two forces work in combination is contingent on the local area, but the more urbanization proceeds in a given place, the more prominent rent seeking through redevelopment and suppression of risk is likely to become.
} 
Quillian 2012), ethnic enclave formation (Wilson and Portes 1980), gentrification (Zukin 1987), and the etiology of place distinctiveness (Molotch, Freudenburg, and Paulsen 2000).

Our conceptualization of residential churning stretches this conventional understanding of invasion to emphasize how it occurs in relation to hazardous industrial churning. We contend that when these two processes occur in close proximity, residential churning obscures physical evidence and clouds public memory of past industrial land uses in ways that can impede successful contestation of industrial land uses by local community groups and facilitate ongoing resettlement of hazardous natural areas produced by earlier iterations of socioenvironmental succession. Moreover, because land-based hazardous wastes can take several generations or more to biodegrade, redevelopment and reuse of formerly industrialized lands by more benign operations can unintentionally uncover buried historic or "relict" wastes (Colten 1990) as demolition and new construction simultaneously erase and expose these lands' earlier industrial histories. In these ways, residential churning and hazardous industrial churning recursively intersect to perpetuate forms of socioenvironmental succession of which they are a part, while also increasing potential exposure of current and future residents to historically contaminated soils that many residents may not even know exist.

We see this process most clearly (but not exclusively) in the redevelopment of historic industrial zones consisting not only of old factories and warehouses but also of modest residences originally built to accommodate factory workers and their families. As subsequent growth machines have inherited these historic, centrally located landscapes, they have found existing single- and multistory buildings particularly amenable to a certain type of redevelopment: gentrification. Broadly, this type of urban reuse harnesses prevailing processes of racial and economic segregation to pull young, white professionals into historic inner-city areas replete with newly refurbished loft apartments, revitalized commercial offerings, and a mix of service jobs in close proximity to the amenities of the central city. In this way, gentrification - and residential churning more generally - operates to obscure the long history of hazardous industrial production that once dominated these natural areas while still allowing it to occur through small and medium-size operations that continue to churn through the area but no longer define its cultural milieu.

These twin dynamics of residential churning and hazardous industrial churning complicate and extend the study of urban environmental inequalities. Whereas work in this field has traditionally focused on contemporaneous proximity of marginalized groups to known (and therefore often regulated) hazardous sites (Mohai, Pellow, and Roberts 2009), our focus highlights the importance of diachronic investigation of longer sweeps of 
history. More recent studies support this analytical shift by drawing attention to how demographic exposure to hazardous sites can change over time, not only with the siting of new facilities in nontraditional areas (Krieg 1995; Downey 2005) but also with the migration of residents to and from hazardous natural areas (Crowder and Downey 2010). Yet even this recent work retains an embedded commitment to synchronic analysis by focusing on historical patterns of residents' proximity to currently operating industrial facilities. Our theory extends this line of inquiry to highlight how residential churning contributes to shifting proximity of different residential groups to current and relict industrial sites over time. The third process in our framework then pushes this inquiry further still, by drawing attention to how regulatory processes often minimize and contain public knowledge about these processes, thereby helping to perpetuate them.

\section{Risk Containment}

As hazardous industrial and residential churning intersect to render accumulations of hazardous sites simultaneously more ubiquitous and less obvious, emergent regulatory processes reinforce and legitimate these contradictory tendencies through risk containment. By risk containment, we refer broadly to the patchwork of environmental regulatory practices that restrict and direct public information about hazardous industrial processes to particular, often visibly contaminated parcels in ways that downplay broader, less visible systemic risks that, if known, would raise public concern, threaten local exchange values, and impede growth machines' profitable reuse of urban lands (Leigh and Coffin 2000). In this way, risk containment operates as a broad, political strategy for acknowledging the dangers of hazardous waste on particular sites while still allowing the core processes of socioenvironmental succession that contaminate such sites to continue, often behind a tangle of local, state, and federal regulations that do more to complicate and thwart civic input than invite and encourage it.

Historically, this strategy of risk containment relied on "out of sight, out of mind" solutions to industrial wastes, treating them like other urban "nuisances" such as sewage, municipal dumps, and cemeteries (Melosi 2008). Industrial zoning policies were developed to distance most city residents from areas of concentrated manufacturing; and waste disposal policies further encouraged manufacturers to release their wastes into the air and water, which carried effluents even farther from local populations. But by the 1950s fish kills and smog in and around urban areas began to raise public concern over increasingly toxic discharges from industrial sources, resulting in new federal monitoring and regulation of air and water pollution. These new regulatory practices better protected air and water quality, but they also encouraged manufacturers to bury growing volumes of hazardous waste on- 
site, channeling it underground in ways that kept it from public view and thus helped to maintain the exchange values of local lands. This arrangement continued largely unimpeded until 1978, when the discovery of thousands of tons of hazardous waste beneath an elementary school in the Love Canal neighborhood of Niagara Falls, New York, brought the once buried consequences of relict hazardous sites to light (Levine 1982).

Since then, Congress has enacted a series of federal regulations that have vacillated between action and inaction and have tacitly bent to the interests of local growth machines, despite well-meaning efforts of dedicated personnel. In 1980, it passed the Comprehensive Environmental Response Compensation and Liability Act (CERCLA, or Superfund), which aimed to minimize problems associated with relict industrial sites but which to date has mostly targeted worst-case parcels that raise the greatest public concern or obstacle to site reuse (Hawkins 1984). In 1986, it passed the Emergency Planning and Community Right-to-Know Act, which requires large facilities to report hazardous waste production volumes, content, and disposal activities but which also waives these requirements for smaller, more numerous waste generators. In 1996, it passed the Brownfield Redevelopment Financing Act, which relaxed legal liabilities for redevelopment of contaminated sites originally created by CERCLA and which through later amendments has provided cities with funds to leverage liability-free redevelopment by private sector investors. As a result, the contamination and reuse of hazardous industrial lands continue, legitimated by a regulatory regime that does not scope risk so much as contain it politically by ignoring the vast majority of older and smaller sites where hazardous wastes continue to accumulate.

\section{Research Implications}

To demonstrate the utility of this theoretical framework, empirical analysis must accomplish five things. It must historicize data collection by working forward from past sites of hazardous industrial production to capture forgotten as well as known sites of concern. It must count all such sites, not just those under current regulatory review. It must integrate analysis of industrial and residential churning to track how these processes intersect to form hazardous natural areas that expose different groups to local hazards over time. It must gather data on site reuse to better understand how these diachronic processes appear to current residents and policy makers. And ideally it must do all of these things through a comparative design that guards against idiosyncrasy and aids in theory testing and refinement. The analysis below embraces these challenges. We start by explaining the logic of our case selection for the comparative design and then describe our innovative approach to data collection and analysis. 


\section{HISTORICAL-COMPARATIVE RESEARCH DESIGN}

Following the logic of Mill's (1906) method of difference, we select cases to maximize variation on key variables across a limited number of generally similar cases. All four cases are older cities, located on major rivers with pre-World War II port facilities that have taken in vast amounts of natural resources and spun off a diversity of local manufacturing activities. All four cities have also long dominated their regional economies and exist outside the core rust belt region, where most prior research on urbanindustrial hazards has focused. These study cities include Minneapolis, New Orleans, Philadelphia, and Portland, Oregon, which we select to demonstrate the generalizability of our theoretical framework and to assess how constituent processes of socioenvironmental succession unfold in cities that vary significantly along several key dimensions.

One dimension is the demographic size of the encompassing metropolitan area. Although Noyelle and Stanback's (1984) classic typology classifies all four areas as "regional hubs" within the national settlement system, by the mid-20th century, Portland and New Orleans were among the smallest of these hubs, and Minneapolis and Philadelphia were among the largest. Another key difference is regional geography. Each historic river port city is located in a different region of the country, offering potential insight into the extent to which regional variation matters for processes of socioenvironmental succession. For example, while Philadelphia's economy grew and diversified much earlier than the others, oil and natural gas extraction continues to dominate New Orleans' local economy, while the economies of Minneapolis and Portland have become relatively diverse over the past half century, each exhibiting a more prominent and ongoing mix of primary processing, heavy industry (e.g., shipping), and light manufacturing.

The four study cities also vary significantly by racial composition and residential segregation, which prior research identifies as important factors in the production and distribution of environmental hazards, particularly in urban areas (Pellow 2000). At the turn of the 21st century, AfricanAmericans made up the largest racial group in both New Orleans and Philadelphia, accounting for $68 \%$ and $45 \%$ of each city's population, respectively. By contrast, African-Americans made up only $15 \%$ of Minneapolis's population and $6 \%$ of Portland's population. Similar differences exist with respect to residential segregation. For example, the black-white index of dissimilarity at the turn of the 21 st century was 70 (out of a possible 100) in New Orleans and 81 in Philadelphia - levels considered high by national averages. By contrast, the same index was between 57 and 58 in Minneapolis and Portland-levels considered moderate by national averages.

Finally, there is local environmental regulation. At one end of the continuum lies New Orleans, a city noted among environmental historians 
and geographers for repeated failures to create and enforce effective industrial zoning, which has encouraged the abandonment of many blighted industrial properties (Colten 2005; Kelman 2006). At the other end lies Portland, an iconic "green" city whose identity as such dates to a 1973 Oregon state law requiring an "urban growth boundary" that encourages site reuse within the urban core and that today engages in extensive review of contaminated and potentially contaminated industrial sites relative to other cities under investigation (Abbott 1983). Minneapolis and Philadelphia fall between these two extremes.

\section{DATA}

Data collection for each city involved an innovative, four-stage process. First, we identified dominant industrial sectors releasing hazardous wastes to on-site lands in each city using data from the (earliest available) 1988 Toxic Release Inventory (TRI) assembled by the U.S. EPA (2011). While relying on TRI data does not ensure that we capture all local industries that have routinely and historically deposited significant amounts of hazardous waste to on-site lands, it does provide a reliable sample at the midpoint of our historical investigation, which runs from the late 1950 s to late 2000s. With these data, we identify five sectors that have been consistent and prominent on-site polluters in all four cities. These include primary metals, fabricated metals, chemicals, industrial machinery, and transportation equipment (mostly shipbuilding). To these five sectors we add two that are not listed as significant sources of toxic releases during the 1980s, when TRI data were first reported, but which historical research identifies as common onsite waste disposers in these cities during the post-World War II era: petroleum refining and plastics/rubber production. While we cannot say for certain that all of the sites in our database are in fact contaminated - an important challenge for future work - prior research by Noonan and Vidich (1992) confirms that the average prevalence of on-site contamination in these sectors is extremely high, ranging from an estimated $83 \%$ among sites of primary metals production to $95 \%$ among sites of oil refining and plastics manufacturing.

To locate sites where these seven sectors have operated and likely deposited waste, we followed prior research by Krieg (1995) and Downey (2005) and consulted state manufacturing directories, which respective departments of economic development have helped to compile and distribute regularly since the mid-1950s. Because a listing in these directories typically requires a small subscription or processing fee from participating manufacturers who are also identifiable on state tax rolls, annual updates are broadly considered reliable. Building a longitudinal database from this source allows us to cap- 
ture relict sites where hazardous industry ceased operation prior to TRI reporting; it also allows us to capture smaller polluters that TRI reporting ignores but that prior research shows can add up to pose significant cumulative risks to nearby residents (Lejano and Smith 2006). To build our database we begin in 1956 and proceed every other year through 2008, identifying every site operating in each targeted sector in each city. To minimize the possibility of mistakenly including corporate offices rather than actual manufacturing facilities, we excluded P.O. box addresses as well as addresses identified as headquarters or home offices. For each remaining facility site, we collected data on street address and years of operation as well as information on firm name, number of employees, and products manufactured on-site.

For the years 1956-2008, these data collection procedures identified 871 hazardous industrial sites in New Orleans, 2,818 in Portland, 3,760 in Minneapolis, and 3,899 in Philadelphia. Note that if two or more hazardous waste manufacturers occupy the same site over time, the site is counted only once in our database. This approach is consistent with our analytical focus on urban land - not specific manufacturers - and ensures that we avoid double counting parcels occupied sequentially by different hazardous manufacturers. Of the 11,348 distinct sites in our database, 95\% (or 10,819) had ceased hazardous operation by 2008, making them relict sites in our terminology. During hazardous operation, which averaged 10 years (with a median of 5 years), mean and median numbers of employees were 57 and 13, respectively, with the most prevalent sectors being fabricated metals $(33 \%$ of sites) and industrial machinery (31\% of sites). The least prevalent sectors included primary metals ( $5 \%$ of sites) and petroleum manufacturing ( $2 \%$ of sites). ${ }^{7}$

Next, to track residential churning, we merged these facility-site data with tract-level data collected by the U.S. Census Bureau. For 1950 and 1960, these data come from the Bogue Data Files that are available electronically from the Inter-University Consortium for Political and Social Research. For 1970-2000, these data come from decennial censuses compiled by Geolytics' Neighborhood Change Database. And for 2008 - the last year of observation - these data come from the American Community Survey's 5-year estimates. We standardize all data to constant 1950 tract boundaries within 1950 city limits, which means that we observe the same, constant spatial units over time for all historical analyses. In most cases, tract boundaries within the respective urban core remained identical over

\footnotetext{
${ }^{7}$ Petroleum manufacturing involves the production of paving and roofing materials and lubricating oils and greases from purchased materials; it does not include manufacturing and distributing gasoline to consumers, which are classified under public utilities sectors, or establishments primarily engaged in producing coke and other by-products, which are classified under primary metals (U.S. Department of Labor 2013).
} 
time, simplifying standardization in ways that would have been more difficult in rapidly growing suburban areas. In other cases, the 1950 tract simply split into two or more tracts that we reaggregated to conform to original, historic boundaries. The result is 59 historically observable tracts in Portland, 84 in Minneapolis, 114 in New Orleans, and 235 in Philadelphia.

To assess current site reuse, we then randomly sampled 100 sites from our facility-site database for each city. We then conducted an in-person survey of each sampled site between 2009 and 2011 to document current land use and to record the character of the surrounding block (e.g., whether it was primarily commercial, residential, or a mix of the two). At each site, we took digital photographs and used detailed satellite maps to refine field observations and maximize data quality. For sites that appeared to be in commercial operation, we consulted company websites, local business directories, and the EPA's TRI records to determine whether these operations were hazardous. If the respective facility operated in one of the seven hazardous sectors designated above or was listed in the 2010 TRI database, we coded the site as still in hazardous operation; otherwise, we coded it as nonhazardous.

As a final step, we consulted each state's Department of Environmental Quality (DEQ) website in 2011 to determine the extent to which hazardous sites in our historical database have been publicly identified and investigated by regulatory agencies. Such regulatory review and public reporting vary greatly across the four cities, and to highlight the range of these public records of hazardous sites we focus on the most and least comprehensive cases: Portland and New Orleans. In Portland, DEQ maintains an extensive Environmental Cleanup Site Information database to track and report all sites with known or potential contamination from hazardous substances. It also documents sites where DEQ has determined that no further action is required. All of this historical information is publicly accessible online. By contrast, in New Orleans, DEQ limits such public reporting to sites engaged in its Voluntary Remediation Program, which uses investor tax credits to incentivize brownfield redevelopment on larger, targeted sites.

The result of this novel, four-stage data collection strategy is a comprehensive multilevel, historically comparative database that is keenly sensitive to the temporal and spatial dynamics of socioenvironmental succession associated with industrially produced hazardous sites. Even with these empirical advances, however, several limitations remain. One is a lack of data on the physical size of respective sites, many of which occupy less than a city block, which is consistent with municipal brownfield inventories showing average lot sizes of "well below one acre" (Wernstedt et al. 2004, p. 8; see also Miller et al. 2000a, 2000b). Another limitation is a lack of data on the volume or toxicity of land-based hazards on-site. Future research may wish to investigate this issue further by using toxicity-weighted pollutant 
estimates (see Woodruff et al. 2009; Sadd et al. 2011) or utilizing public records to generate more detailed historical data on specific sites (e.g., Litt and Burke 2002). Finally, our data do not include hazardous sites once occupied by retail establishments such as gas stations or dry cleaners that do not produce but do store - and leak-hazardous materials on-site. Future research may wish to extend data collection in these directions, but for now the present study offers an unprecedented inventory of urban lands likely contaminated by manufacturing processes that increased greatly in diversity, volume, and toxicity during the mid-20th century.

\section{RESULTS}

\section{Hazardous Industrial Churning}

Figure 1 graphs the historical accumulation of relict sites of hazardous industry atop contemporaneous counts of active sites disaggregated by facility size, which we measure as the mean number of employees during hazardous operation. Results indicate that the number of active sites across the four study cities has remained surprisingly constant over the past half century-between 2,000 and 2,300 sites-despite significant industrial, demographic, and regulatory change. Results also show how the churning of a relatively constant number of active sites can feed a steady accumulation of relict sites over time. Our analysis indicates that such churning produced more than 9,400 relict sites between 1956 and 2008, or roughly 180 sites per year across the four cities. Further analysis indicates that $78 \%$ of these relict sites ceased hazardous operation before CERCLA implementation in 1983 or never exceeded nine employees, which means that the sites avoided environmental regulation while in operation and likely have ever since.

To test whether small hazardous facilities became more likely to stay small after 1983 and thus avoid such regulation, we fit a simple logistic regression model for all "ever small" facilities ( $<10$ employees) that had ceased hazardous operation by 2008 (to avoid right censoring). The dependent variable was a simple dummy indicator of whether the hazardous facility ever employed 10 or more employees and thus became subject to regulation. Results (not shown) indicate that before CERCLA's implementation, 64\% of small facilities remained small before exit; after implementation, $80 \%$ remained small $(P<.001)$. So not only do small facilities contribute substantially to the accumulation of relict sites over time and space, they do so in ways often missed by new government reporting requirements, further underscoring the need for research strategies that include hazardous facilities of all sizes, not just those covered by new regulations.

Next, to assess the generalizability of these dynamics across cities and how they become spatially uneven over time, we shift analysis from indi- 


\section{Urbanization as Socioenvironmental Succession}

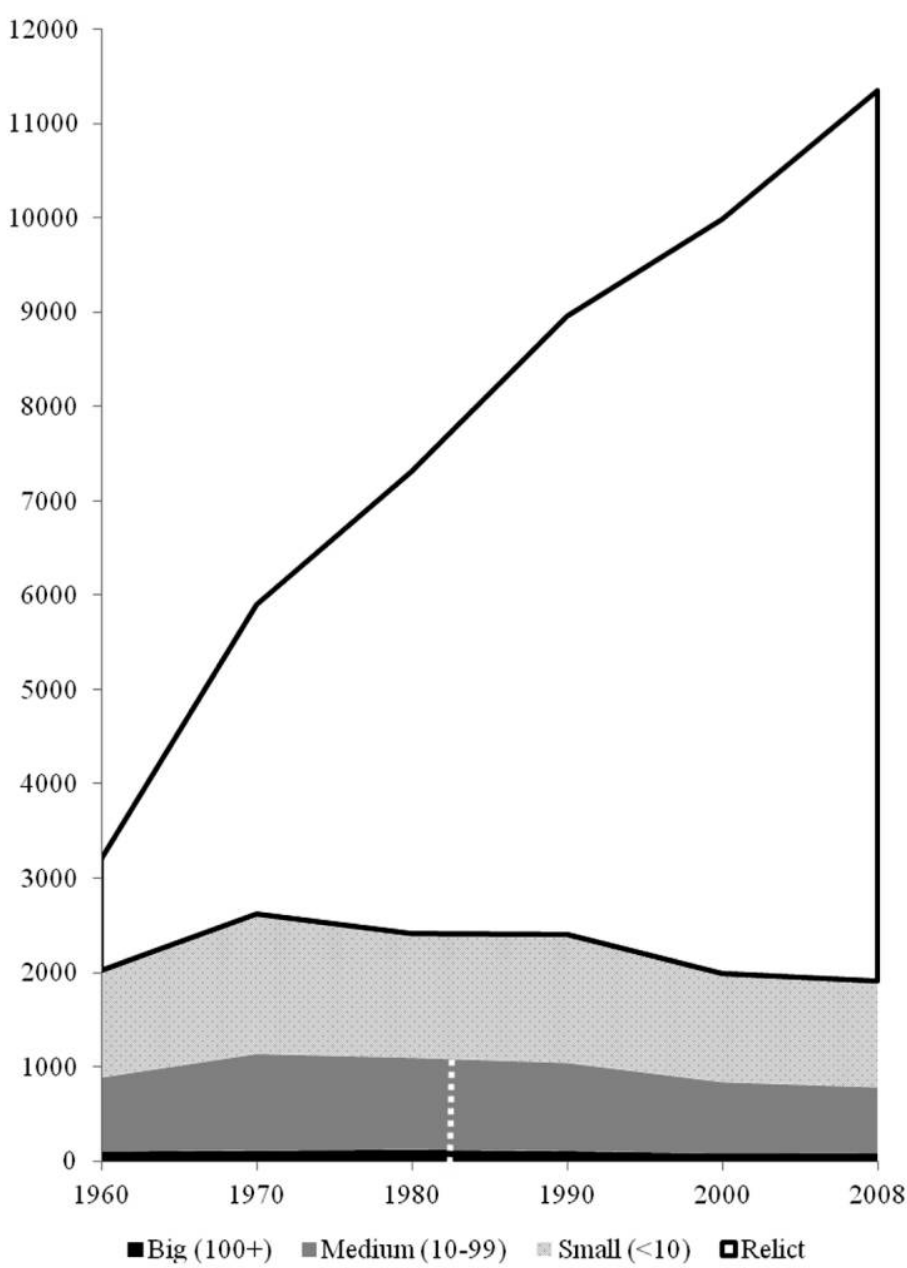

FIG. 1.-Stacked area graph of active sites (by workforce size) and all observed relict hazardous sites in our four study cities, 1960-2008. Relict sites in this study begin accumulating after the first observation in 1956, which implies a four-year lag prior to 1960. Implementation of federal CERCLA regulations (1983) and TRI (1988) cover only manufacturing facilities that employ 10 or more full-time-equivalent workers and report processing more than 25,000 pounds of toxic chemicals per year (initially it was 75,000 pounds).

vidual sites to historic census tracts, using standardized 1950 boundaries. To control for variation in tract size and thus spatial opportunity for local hazard accumulation, we compute the spatial density of active and relict sites per square mile. We do this for each tract at the start of each decade, ending in 2008, the last year of observation. Figure 2 displays means and 
Portland
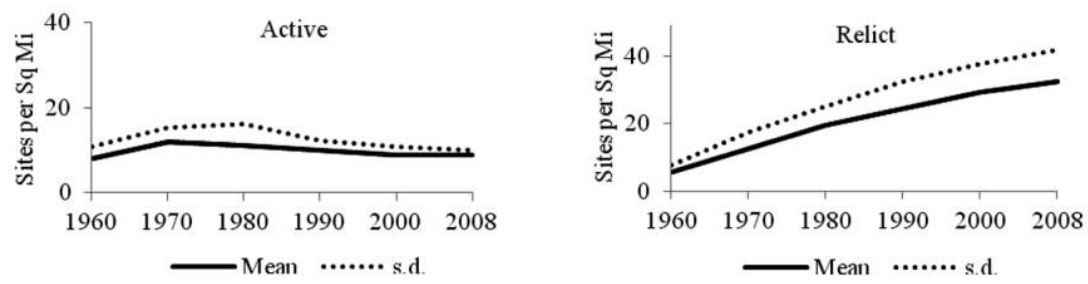

New Orleans
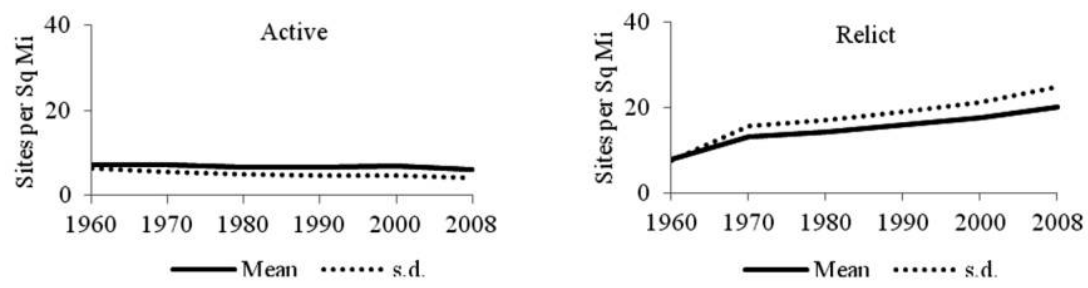

$\underline{\text { Minneapolis }}$
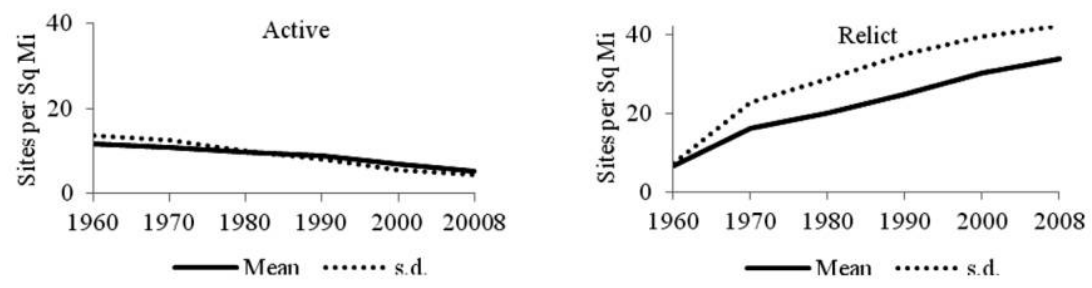

Philadelphia
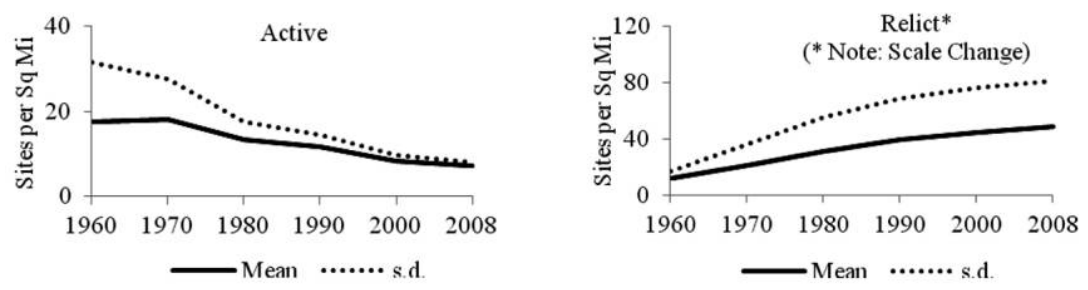

FIG. 2.- Tract-level means and standard deviations for active and relict sites per square mile by city, 1960-2008 (in ascending order of average demographic size during the late 20th century). 
standard deviations for these two variables in each city over time, revealing several important trends.

First, results affirm that relict sites continue to accumulate steadily in each city, even when the average density of active sites holds steady or declines. ${ }^{8}$ Thus, as a general rule, relict sites increasingly outnumber active sites. A stark example is Philadelphia - the largest of the four cities. By 2008, active sites averaged seven per square mile, but relict sites averaged more than 10 times this number. Indeed, some tracts reached more than 500 relict sites per square mile, which if distributed evenly over space would yield a site every 90 yards.

Yet, as classical human ecology predicts, the distribution of hazardous sites over urban space becomes increasingly uneven over time. Standard deviations across local census tracts provide a simple means of demonstrating this spatial dynamic, which sets the structural foundations for environmental inequality. Figure 2 shows that as the average density of active sites holds steady or decreases in a city, variation in local densities holds steady or decreases also, as industry continues to churn across previously unindustrialized lands. But these statistics also show that as the average density of relict sites increases in a city, so too does variation in local densities of relict sites - which over time increasingly outnumber active sites. This intensifying dynamic implies that as hazardous industrial churning occurs, it not only affects more and more parcels of (newly industrialized) urban land but also scales up in certain areas to create hazardous natural areas with increasing densities of relict sites per square mile.

In this way, industrial churning operates temporally and spatially in ways that produce seemingly paradoxical results: as active sites stay or become relatively more evenly distributed at any given point in time, over time, relict sites accumulate in ways that are increasingly uneven. These endogenous and largely hidden processes in turn raise questions about who lives nearby and how answers to this question change over time, as residential churning occurs and relict sites continue to accumulate.

\section{Residential Churning}

To investigate who lives in tracts with increasing densities of active and relict sites and how these patterns change over time, we add census data to create a repeat panel database with six observations per tract, the primary unit of analysis. These observations occur every decade from 1960 to 2000, with a sixth observation in 2008. Using these tract-level data, we estimate

${ }^{8}$ In theory, spatial density of active sites may decline because the number of active sites decreases over time or because the location of active sites becomes more widely distributed over time or a combination of both. 
fixed-effects regression models separately for each city using robust standard errors. Because ecological theory predicts and Moran's I-statistics (below) support the idea that neighboring tracts endogenously interact, all models use a spatial autoregressive specification with maximum-likelihood estimation. In this specification, the average value of the dependent variable in contiguous tracts is included as a regressor in all models (with a coefficient of Rho). We use fixed (rather than random) effects to purge time-invariant variation among tracts (e.g., location along a port or major highway) and to focus on changes occurring within tracts over time. This approach minimizes omitted-variable bias while maintaining conceptual emphasis on local churning, or iterative change.

In these models, all variables except time are log transformed to minimize the influence of outliers and to standardize coefficients for comparison. This approach is similar to elasticity models in economics and scalar models in natural science, which produce coefficients that indicate the percentage change in the dependent variable in response to a $1 \%$ change in the respective independent variable.

The two dependent variables are spatial density of active sites and relict sites in each tract at each time point. Predictors of central interest include changes in (1) time, measured as the respective panel-year minus 1958 (the first year we observe relict sites); (2) median family income, measured in constant 2008 dollars; and (3) racial composition, measured as the percentage of residents considered white in the U.S. Census. Because we are interested in how marginal effects of race and income vary over time, we estimate each model several times: once with main effects for each variable and again with interaction effects for time and income and for time and racial composition, which we include alone and in combination with one another. We then report results of the best-fitting model for each city.

Control variables in all models include (4) total population, which controls for changing residential density; (5) \% owner occupancy, which controls for changing residential (im)mobility; (6) average age of housing stock, which controls for new residential development; and (7) residential vacancy rate, which controls for changing housing demand. Full results appear in table A1. To facilitate interpretation, figure 3 graphs marginal effects for our central variables of interest by city. Subsequent discussion assumes an all-else-equal condition with respect to other factors in the model.

We begin with the spatial density of active sites, which are more readily evident to nearby residents than relict sites because of their contemporaneous operation. Results presented in figure 3 reveal several key patterns. First, in Portland, there is a steady negative effect of income and white presence on active-site density, which is consistent with general accounts of environmental injustice as well as with specific case studies of the city's historic development (Hovey 1998; Stroud 1999). Notably, however, these 

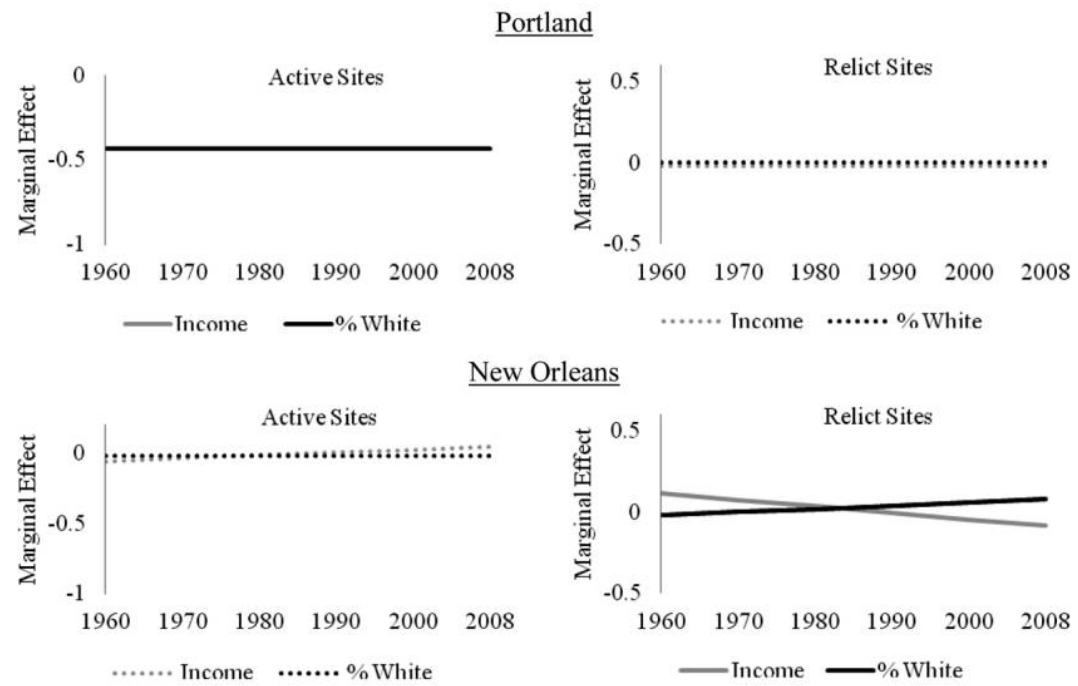

Minneapolis
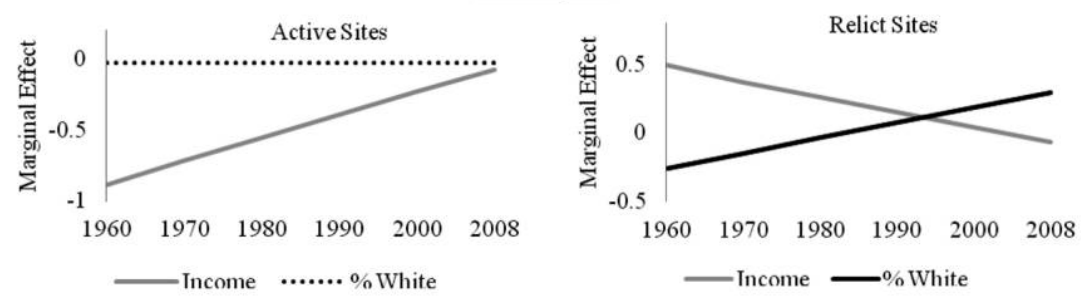

Philadelphia
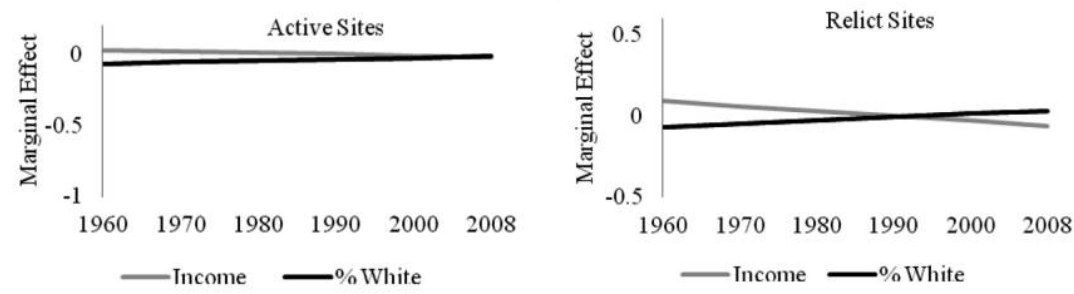

FIG. 3.-Marginal effects of tract-level median family income and racial composition on spatial densities of active and relict sites, 1960-2008. Solid lines are statistically significant at $P<.05$ (two-tailed test); dashed lines are not. See table A1 for full results from spatial autoregressive models using panel fixed-effects specification.

patterns are absent for relict-site density. This divergence implies that in Portland, as hazardous sites cease operation and become relict, they become less off-putting to more racially and economically privileged residents, who are (and have been) as likely to live near them as less privileged residents. 
In the other three cities, we see a different set of patterns. With respect to active-site density, results show relatively little effect (or change in effect) of racial composition over time. And in Minneapolis, where the negative correlation between income and active-site density has been historically strongest, it has declined substantially over time to become negligible by 2008. So patterns evident for active-site density in Portland appear to be more the exception than the rule. The same holds for relict-site density. Whereas in Portland there is little correlation with income and racial composition over time, in the other three cities we see two notable trends.

One trend shows the correlation between family income and relict-site density to be declining steadily over time. This finding implies that as relict sites in New Orleans, Minneapolis, and Philadelphia have accumulated, the mix of residents living nearby has become economically more diverse and less elite. The other trend shows the opposite correlation for white presence, which has steadily increased with respect to relict-site density over time. Together these findings imply that growing numbers of workingand middle-class white residents - most likely, young aspiring professionals - have been churning to, not from, hazardous natural areas over recent decades.

So overall, fixed-effects regression with data on a wide range of regulated and unregulated sites presents a different picture than that commonly offered by synchronic analyses of regulated (i.e., known) hazardous waste sites. Broadly, this picture indicates steady or declining social inequalities in proximity to active sites alongside a churning of white residents toward areas of increasing relict-site density. The exception to this general trend is Portland, where whites and nonwhites are similarly exposed to relict sites, despite lingering inequalities in proximity to active sites. This exception further illustrates how less visible, often forgotten relict sites can accumulate to pose systemic risks that researchers' attention to synchronic inequalities often misses. According to our theory of socioenvironmental succession, these findings do not refute conventional accounts of race- and class-based environmental injustice but rather put them in broader historical context.

However, in revealing this broader context, a fixed-effects approach remains analytically incomplete because it treats census tracts as areas that exist outside historical locations of which they become parts-locations that classical human ecology argues shape local development. To recover this locational context, we offer two complementary analyses. One computes and graphs Moran's I-statistics for the spatial clustering of relict sites across local tracts over time; the other uses kernel-density maps to display where relict sites have come to cluster most heavily by the end of the study period. We present the two analyses side-by-side for each city in figure 4 . 


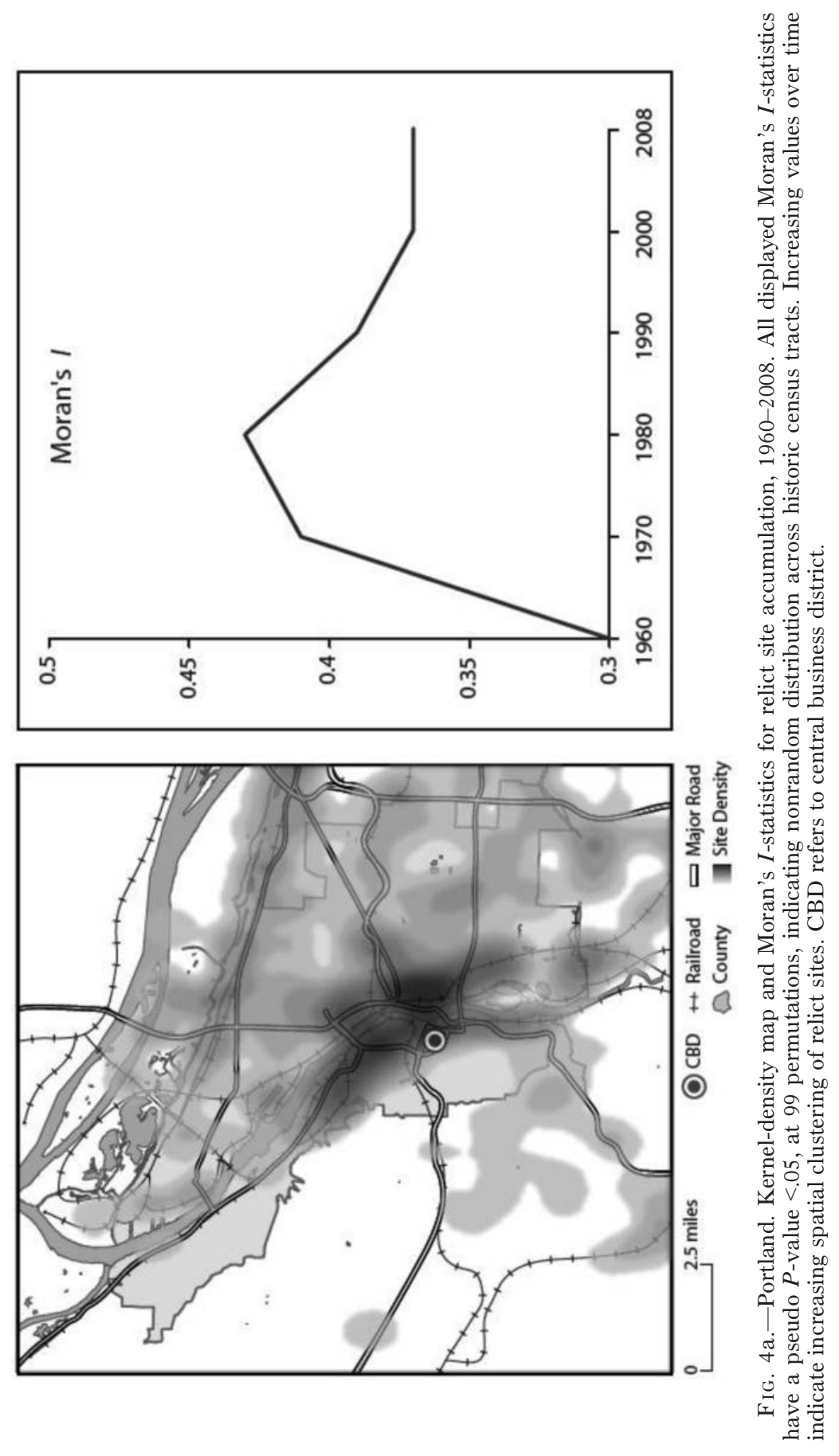

This content downloaded from 128.042.238.003 on May 18, 2017 11:00:55 AM All use subject to University of Chicago Press Terms and Conditions (http://www.journals.uchicago.edu/t-and-c). 


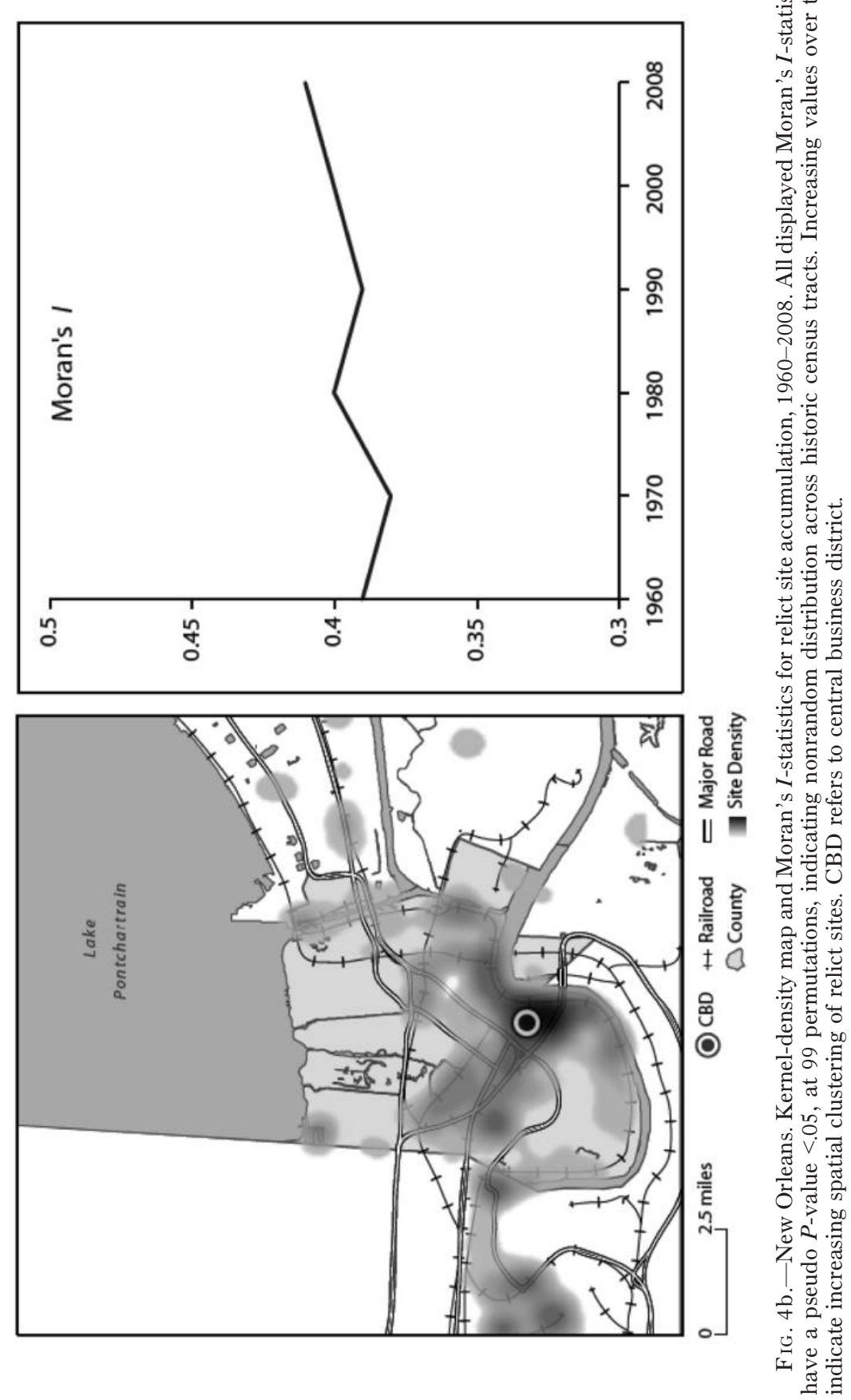

1760 

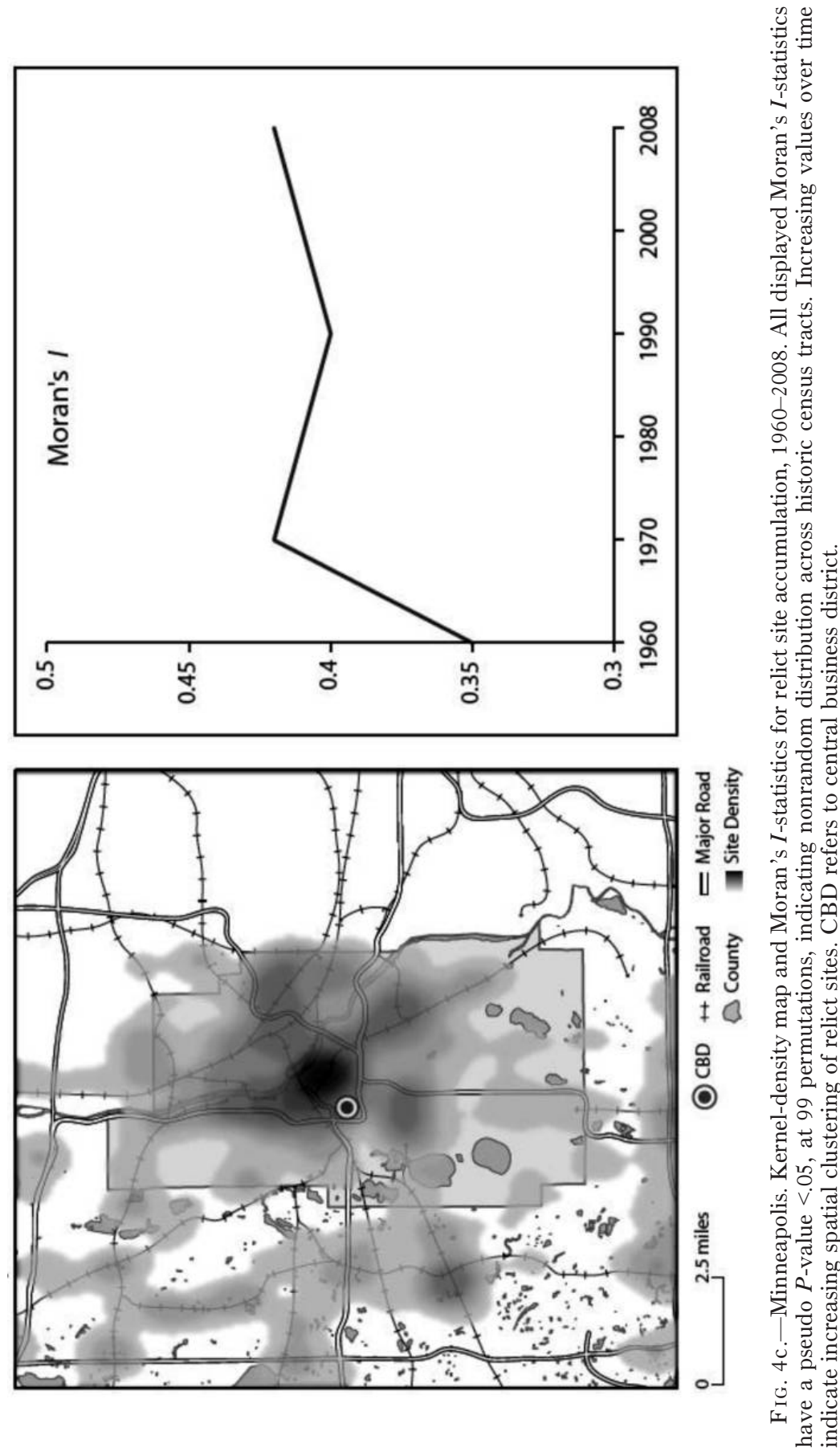

1761

This content downloaded from 128.042.238.003 on May 18, 2017 11:00:55 AM All use subject to University of Chicago Press Terms and Conditions (http://www.journals.uchicago.edu/t-and-c). 


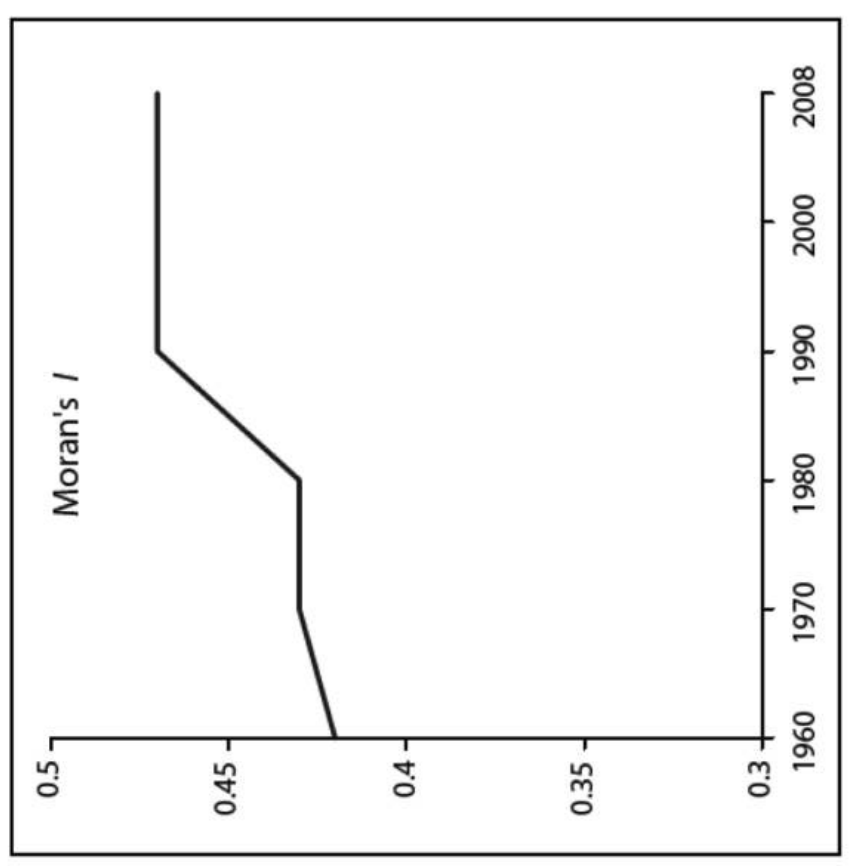

.

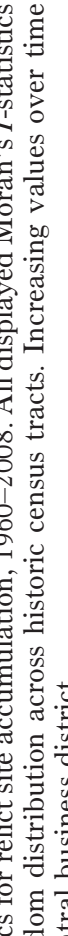

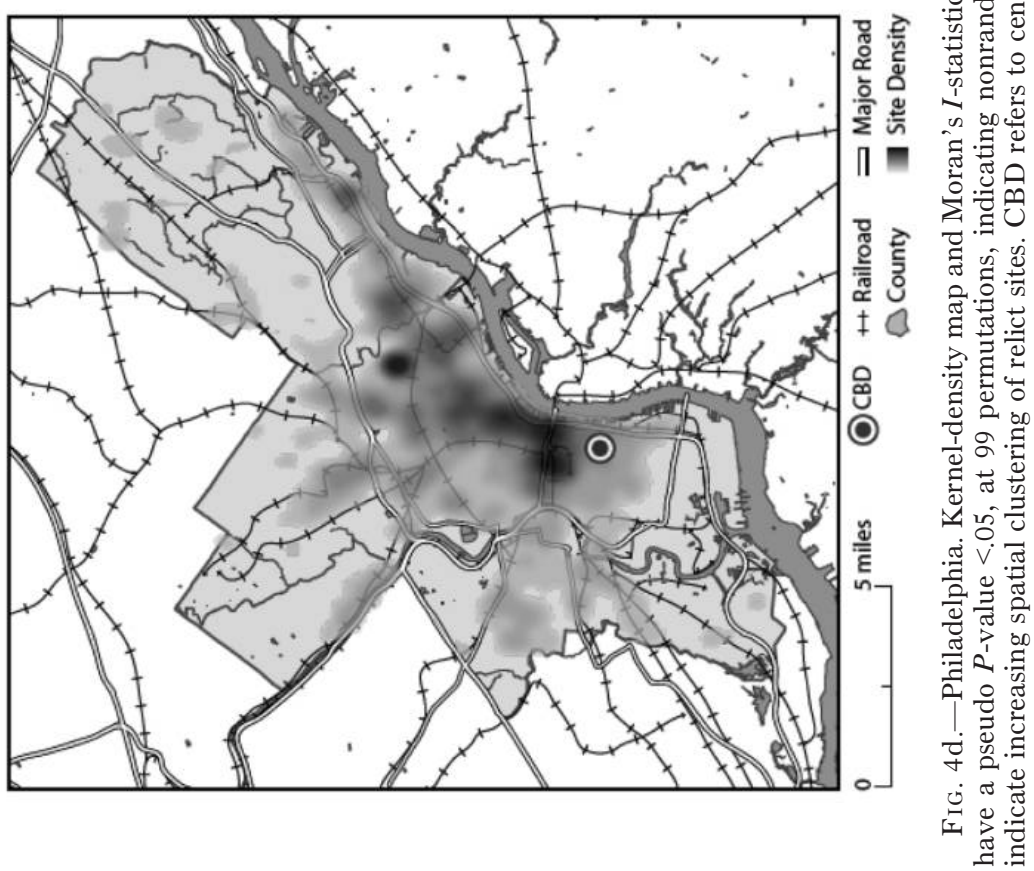

This content downloaded from 128.042.238.003 on May 18, 2017 11:00:55 AM All use subject to University of Chicago Press Terms and Conditions (http://www.journals.uchicago.edu/t-and-c). 
Results for the Moran's I-statistics (and spatial regression results above) are based on a queen-one contiguity matrix that measures spatial autocorrelation in relict-site density among neighboring tracts at respective points in time. ${ }^{9}$ These statistics show Portland again to be somewhat exceptional. Whereas in Philadelphia, Minneapolis, and New Orleans relict sites have increasingly clustered among neighboring areas during recent decades (as indicated by high and increasing Moran's I-statistics), in Portland something different has occurred. As relict sites have continued to accumulate, they have spread more broadly throughout the city (as indicated by declining Moran's I-statistics over recent decades). Yet, in all cases, accompanying kernel-density maps indicate substantial concentration of relict sites in historic industrial zones near the central business district (as indicated by darker shading), with spread along major transit corridors, including local waterways. This is where residential churning associated with gentrification is bringing white residents into increasing proximity with high historic and ongoing accumulations of relict sites.

Overall, these locational dynamics help to refine our understanding of the divergent results presented in figure 3. It now appears that in cities where hazardous industrial churning remains more (but still not completely) concentrated within older, gentrifying zones, we find increasing exposure of white residents to relict sites as they churn into these areas. In other cities, such as Portland, where relict sites are dispersing more broadly throughout the urban core, we see less evidence of shifting variation by race and income over time because the spread of relict sites is becoming more widespread, affecting more groups and areas. So the main pattern observed in Philadelphia, New Orleans, and Minneapolis is also present in Portland, but in Portland this pattern occurs in conjunction with broader spatial diffusion of hazardous industrial churning, which weakens observed relationships with changing economic and racial compositions of local areas.

Now we take a closer look at site reuse and selective regulation, which intersect with residential churning to help contain local risk perceptions politically.

\section{Risk Containment}

Residential churning contributes to risk containment by clouding collective memory of past industrial activities in local areas. But reuse of relict sites remains risk containment's real driver because it erases visible clues

\footnotetext{
${ }^{9} \mathrm{~A}$ queen-one spatial weights matrix is one that includes all neighboring units (i.e., tracts) with shared borders and vertices. Diagnostics show no tracts with zero neighbors ("islands"), no binomial distributions, and no tracts with exceedingly large numbers of neighbors.
} 
of contaminants that may remain buried on-site, which regulation only then selectively brings to light. In this section, we return to the site level to investigate how processes of reuse and selective regulation overlap to mask and propel this form of socioenvironmental succession.

To study site reuse, we rely on the random sample of sites we surveyed in each city between 2009 and 2011. Descriptive results appear in figure 5. They indicate that, by far, the dominant type of site reuse in each city is by nonhazardous commercial and civic facilities. Among the most common enterprises we observed were automotive repair shops, parking lots, preschools, and government offices. But we also observed a wide array of other types, from restaurants and wholesale outlets to hotels and coffee shops. The next most common type of reuse varies by city size. In larger cities such as Philadelphia and Minneapolis, remaining sites were more likely to become vacant lots or public spaces, such as parks or playgrounds. By contrast, in the smaller city of Portland, where local growth boundaries keep manufacturers in the urban core, sites were more likely to remain in hazardous operation. In all cities, however, it is clear that most sites are reused by activities other than hazardous industry.

Next, to learn more about dynamics of site reuse, we estimated two multinomial regression models using robust standard errors. In each model, we predict a three-category dependent variable: (1) still in hazardous industrial use; (2) now a vacant lot or public space (e.g., a park or playground); or (3) now in nonhazardous commercial, civic, or residential use (the modal outcome and the one most in line with contemporary interests of local growth machines). To predict these broad categories of land (re)use, we include several sets of independent variables, all measured in 2008, near the end of our study period.

At the site level, we include (1) the number of years that the site was in hazardous operation since 1956 and (2) whether this operation ever occurred under regulatory purview (i.e., employed 10 or more workers after 1983; $0=$ no, $1=$ yes). At the tract level, we use data from the American Community Survey to include all variables examined in the previous section: (3) median family income; (4) share of white residents; (5) share of homeowners; (6) share of vacant units; (7) mean age of housing units; and (8) total population (all $\log$ transformed). Finally, to test and control for the city-level differences that are evident in figure 5, we include dummy indicators for each city, with Portland serving as the reference.

Full results appear in table B1 and reveal three main findings. First, the longer a hazardous facility operates on a site, the more likely it is to continue doing so. This finding conforms to a basic principle of industrial demography: the best predictor of current activity is the extent of past activity. Second, aside from population size, no other tract-level factors significantly predict type of site reuse - not income, not racial composition, not relative housing 


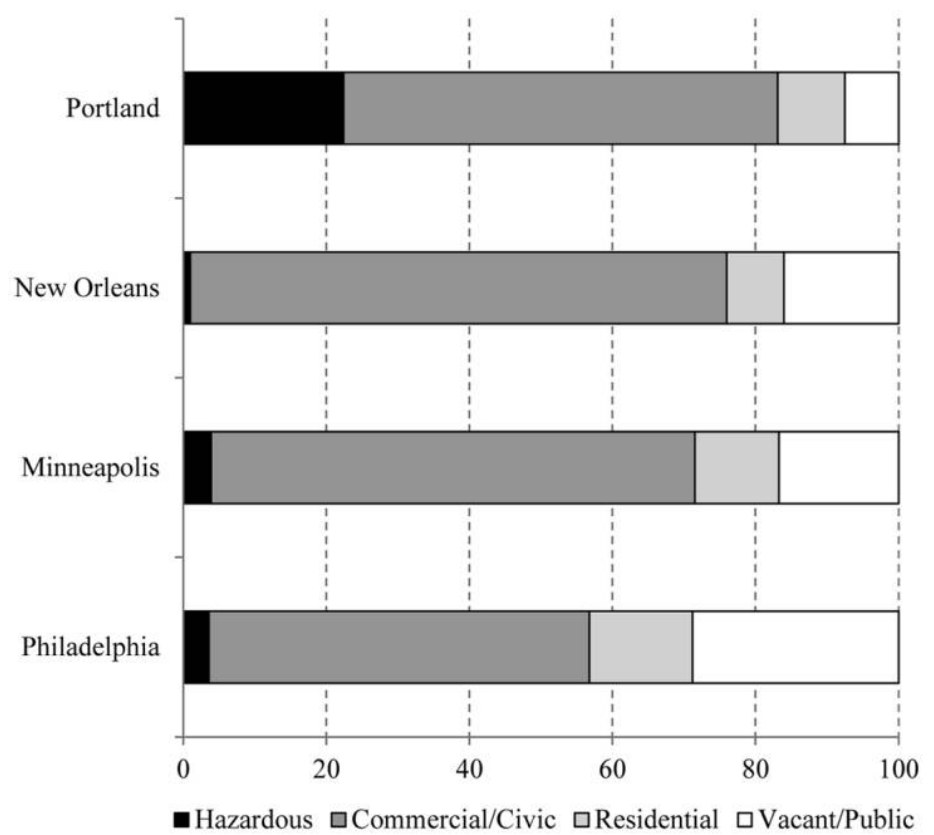

Fig. 5.-Synchronic view of contemporary site (re)use. Data are taken from contemporary site surveys. Valid $N=390$. Numbers in $x=$ axis are percentages.

demand, not the average age of local housing stock. This pattern affirms that current neighborhood characteristics offer few clues about past industrial activities and relict wastes that may still linger. Third, sites where hazardous industry operated under regulatory purview are less likely to become vacant or public lots. This finding is consistent with the idea that environmental regulation is as much about encouraging revenue-generating reuse of urban lands as it is about exposing the full extent of hazard accumulation.

To document how regulation illuminates only a small fraction of such accumulation, we take a closer look at how officials have applied pertinent environmental regulation. This line of investigation is important because if hazard assessment has been active and widespread, then reuse of relict sites may reflect intensive review and remediation - the opposite of hazard obfuscation and risk containment. For this investigation, we focus on two cities widely considered to be among the best and worst at such environmental regulation: Portland and New Orleans, respectively. In each city, we obtained publicly available lists of hazardous sites registered with each state's DEQ. Note that these lists include former sites of concern that have undergone CERCLA phase 1 environmental assessment, which means the lists are historically cumulative. 
In New Orleans this publicly available list comes from the state's Voluntary Remediation Program Sites List for Public Record and includes only 18 sites (Louisiana DEQ 2011). The list is short because state and local officials provide public information only for cases where property owners (or potential owners) seek release of liability after cleaning up historical contamination on-site. This means that information is restricted to bestcase scenarios where actions have been taken to quell rather than raise public concern. In Portland, the publicly available list contains more than 700 sites and is much more extensive because state and local officials report all "contaminated and potentially contaminated sites" they review, regardless of when suspected or identified hazardous waste was deposited on-site (Oregon DEQ 2011).

Of the 18 relict hazardous sites publicly listed in New Orleans, none were in our database. This finding implies that the 871 sites we uncovered in the city have entirely escaped local environmental review and reporting. In Portland, the public list of 716 sites netted only $6 \%$ of the 2,818 potentially hazardous sites uncovered by our study. Further investigation reveals that most of these publicly identified sites were historically occupied by large facilities that employed more than a hundred workers, making them not only more likely to linger in public memory but also of sufficient size to invite large-scale, publicly leveraged redevelopment. These findings coupled with those above affirm that, intentionally or not, retrospective regulation of hazardous urban parcels - even when pursued aggressively by state and local regulatory agencies - amounts to, at worst, a strategy of risk denial and, at best, a strategy of risk containment in which larger, more visible sites tend to be identified and potentially remediated for reuse.

\section{CONCLUSION}

Sustainable societies of the 21 st century require sustainable cities. Setting this foundation in place will be a monumental challenge given that urban areas already account for $80 \%$ of the planet's material consumption and during the next 80 years will add 3 billion more people through migration to new and existing areas, continuing a wave of urbanization unprecedented in world history (Peter and Swilling 2012). If this transformation is to move human societies in the direction of a more sustainable future on planet Earth, we must better understand how urbanization has unfolded in the past and how related processes and outcomes will continue to shape our urban futures.

Toward that goal, the present study has advanced a theory of urbanization as socioenvironmental succession and has initiated an empirical basis of support for this conceptual project. The theory holds that urbanization is 
usefully viewed as an endogenous process of historical change constituted through continuous entwining of urban social and natural systems. This socioenvironmental succession unfolds in particular places and times to create temporally and spatially distinct outcomes, with the accumulation of hazardous wastes from industrial sources being a characteristic of urbanization since the early 20th century. Particularly after World War II, this form of socioenvironmental succession has been driven by three intersecting and recursive processes. Industrial churning has continued to fill in older areas of cities with land-based hazardous wastes that run into the billions of pounds annually and that continue to accumulate temporally in place and spatially from parcel to parcel. Over time, this churning has scaled up to create and spill over from hazardous natural areas that residential churning obscures by altering local residential groups, cultural routines, and the built environment, thereby expunging collective memories of past land uses. In this way, once visible hazardous industrial sites are gradually erased from view and become hidden, or relict. This ongoing production of relict sites is now reinforced by regulatory regimes guided by the logic of risk containment, whereby entrenched political-bureaucratic practices within well-meaning regulatory agencies systematically overlook the full extent of manufactured risks associated with ongoing industrial production. Intentionally or not, these processes converge to promote land reuse and preserve exchange values in urban areas that become more polluted with time. This understanding has important implications for urban residents and offers several contributions to existing theory, methods, and policy.

\section{Theory}

In theorizing socioenvironmental succession, we offer a synthetic framework that connects and extends core theoretical traditions in urban and environmental sociology. Foremost, this framework rehabilitates classic concepts of ecological succession and natural areas to illuminate how urbanization operates as a richly textured, endogenous process that mutually transforms local social and natural systems as it draws resources from other places in ways highlighted by macrohistorical political economy. Our approach also complements emphasis placed on the circulation of material resources and wastes in the growing literature on urban metabolism by showing how the byproducts of industrial production do not just circulate but also accumulate, fundamentally altering the literal, biophysical basis of cities - their soils.

In addition, our theory encourages a deeply contextualized understanding of urbanization across broad sweeps of time in a way that is sensitive to the particularities of place history (Abbott 1999). It does so by extending urban sociology's conceptualization of local growth machines (Logan and 
Molotch 1987) to historicize relevant political-economic dynamics and by connecting these dynamics to the driving logic of urban land reuse, through which endogenous processes of socioenvironmental succession iteratively retake and remake place. This extended focus on successive change highlights how each effort to gain control over each contested parcel contributes incrementally to a much broader and ongoing process of socioenvironmental change. In doing so, our theory links with broader developments within environmental studies that seek to move beyond the question of how social forces (such as urbanization) act on nature to better understand how these processes work through nature, not only to produce value for those in power but also "new ensembles of nature-society relations" (Moore 2011, p. 36). As such, urban growth machines are neither social nor environmental, in the conventional sense. Rather they embody and express broader interactions between the symbolic (e.g., risk) and the material (e.g., hazard) world-interactions that both constitute and explain socioenvironmental succession.

In contributing to these broader developments, however, our theory also remains deeply materialist. Changes in urban industrial economies, social demography, and entrenched regulatory regimes are important for our theory because they help to explain not only how urban residents, workers, and developers use land but how that land is thereby transformed through biochemical changes brought by iterative land use conversions. This materialist orientation, which views biophysical hazards as preconditions of socially manufactured risk, helps to correct the excessively cultural focus of early human ecology (Park 1925) as well as more contemporary theories of risk society (Beck 1992) to advance empirical investigation of the historical production and spatial distribution of risk and environmental inequality. With respect to the latter, our findings suggest that the situation facing urban residents is potentially more complex than most previous research acknowledges. The present study builds on recent efforts to better understand this historical complexity by illuminating how synchronic inequalities observed at given points in time are embedded within broader diachronic processes that ultimately shape who lives and works near hazardous natural areas as those areas shift, expand, and change value over time.

\section{Methods}

The methodological approach we develop to assess and refine this conceptual project is innovative in several ways. It advances an original, multicity data collection strategy that is highly detailed and sensitive to changes at the parcel, neighborhood, and urban scales for over a half century and combines this effort with state-of-the-art statistical analyses. These methodological advances and the conceptual architecture behind them begin to 
lay foundations for a historical-comparative environmental sociology of cities.

Building a bank of empirical data to further advance this ambitious agenda will not be easy. Extant studies rely heavily on secondary data made available by regulatory agencies and municipal governments in the form of hazardous waste or brownfield site lists. Yet the data contained in these lists are not standardized and can vary widely from city to city and state to state. Federal EPA databases such as TRI or Risk-Screening Environmental Indicators, while more consistent, are systematically biased in ways documented by prior research (e.g., Crowder and Downey 2010; Grant et al. 2010) and reflected in a shifting legal terrain of loopholes, waivers, and exemptions in environmental policy. None of these data, moreover, reach back in time prior to the mid-1980s, truncating researchers' ability to develop longer-term historical analyses. And perhaps most important is that available secondary data do not include the full range of sites necessary for understanding the historical and spatial dynamics of land (re)use and identifying what sites of hazardous industrial production become over time.

Our theoretical focus on historic urban cores helped us to overcome these empirical challenges. Future attempts to extend this effort into the suburbs are likely to prove more challenging because of the greater fluidity of suburban boundaries and census tracts over time. However, these challenges can also provide powerful motivation, pushing researchers to build data consortiums and to work more intensively and interactively with new technologies such as Geographic Information Systems and Bayesian spatial statistics. These efforts might help to extend relevant units of analysis from the urban to metro scale to better assess how key processes of socioenvironmental succession diffuse spatially through multinodal regions over time.

\section{Policy}

The present study also contributes to policy by pointing to several pressing gaps. The first recognizes that local production and distribution of hazardous industrial sites are more extensive than current or past regulatory practices reliably document and that risks associated with those potentially contaminated soils, in turn, are correspondingly more systemic than existing policy typically acknowledges. These gaps suggest that measurably decreasing a city's toxic load will require much more than testing, remediating, and redeveloping a few large, highly contaminated industrial lots that represent only a small fraction of a city's cumulative acreage of industrialized lands. Such policy gaps are deepened by want of resources to address systemic risk and lack of institutionalized mechanisms to identify sites of relict industrial waste. As a result, the implicit "out of sight, out of 
mind" principle that has guided regulatory practices for more than a century (Colten and Skinner 1996) continues largely uninterrupted as government agencies further relax legal and regulatory structures that rely increasingly on voluntary reporting by industry.

Such deeply rooted gaps create conditions for misguided or poorly aimed policy, which can become further compromised within a U.S. federalist structure that invites significant variation across state and municipal levels. And these conditions need not be deliberate or ill intended. For example, at the federal level, our findings demonstrate how environmental regulations developed to reduce air and water pollution have not slowed the accumulation of land-based hazards, despite decades of deindustrialization and gentrification. At the state level, our findings also hint at how well-meaning policies intended to bring jobs back to inner cities through publicly subsidized, limited-liability redevelopment can encourage vastly different practices within state DEQs charged with protecting public health. And, at the municipal level, our findings demonstrate how model programs such as those developed in green cities like Portland - with its metropolitan governance board, urban growth boundary, investment in alternative transit, and institutionalized neighborhood associations - can foster conditions that unintentionally propel the systemic accumulation and distribution of industrial hazards across local areas over time. As a result, the systemic scaling up of land-based waste disposal activities - the root source of the problem - continues largely unimpeded, even as environmental inequalities associated with contemporaneous exposure to large, active sites continue to warrant sustained attention (Saha and Mohai 2005).

\section{Strategies for Future Research}

We believe these contributions go a long way toward demonstrating the value of our efforts to develop a synthetic framework for theorizing and studying urbanization as socioenvironmental succession. But much work remains to be done. Two general strategies seem to us to offer the best opportunities to further refine and extend the approach developed here. One strategy is to go deep; the other is to go wide.

Going deep might provisionally involve coordinated efforts to develop detailed community histories of hazardous natural areas (e.g., Hurley 1995) in ways that progressively contextualize their emergence through sociospatial interactions with surrounding areas and urban-level institutions. Digging past classical human ecology's study of the cultural dimensions of local areas - illustrated by Zorbaugh's "The Natural Areas of the City" (1926) and The Gold Coast and the Slum (1929)—-these new socioenvironmental community histories could link to toxicity-weighted pollution estimates from the U.S. EPA to better estimate the changing profiles of risk that are 
associated with different patterns of hazardous waste accumulation in different cities or in different parts of cities. Such efforts might also extend analysis of socioenvironmental succession to relict wastes in urban lake or river sediments and to related risk containment strategies that include fish consumption advisories and safe eating guidelines in and around many older urban areas. Additional efforts could also trace the accumulation of knowledge from genetic and toxicity studies associated with different industrial contaminants to illuminate ways that regulatory practices produce knowledge (or not) about locally significant contaminants (Frickel and Edwards 2014).

Alternatively, going wide might examine cases beyond soil-based hazards to see whether socioenvironmental succession is indeed generalizable and whether understanding other types of cases in such terms is analytically useful not only in isolation but also for developing the theory more generally. Possible topics - not all of which need have deleterious outcomes - might include studies of "localist movements" for greening cities, say, through urban agriculture, which seeks to reuse urban lands in progressive ways but which also risks perpetuating utilitarian views of nature, as farmification reduces the ecological diversity upon which it depends (Hess 2009; Bartomeus et al. 2013). Another topic might include disaster recoveries, wherein cultural responses to extreme weather events-which occur regularly and thus constitute a normal and ongoing part of our interaction with the natural world - encourage local growth machines to use new sources of material and symbolic capital that become available after major catastrophes to increase the scale and scope of local vulnerabilities to future interactions in successive fashion (Pais and Elliott 2008).

These possibilities offer only a few instances of what remains a much broader invitation to urban and environmental researchers to join us in developing a larger, more integrative family of databases, cases, and comparisons that are needed to untangle the complex trajectories and outcomes of socioenvironmental succession in cities. Older cities, such as those we have targeted in this study, are particularly valuable in this regard, helping us to better understand urbanization as a long-term set of prospects and challenges that will continue to confront human populations that are increasingly urban on a planet stressed by climate change and growing resource scarcities. The underlying point is that the human future will be an urban future; of that we can be sure. What remains in question is whether that future is bright or bleak. The answer will depend in part on our ability to accurately understand the dynamics that drive the socioenvironmental succession of cities, where past always remains present. 


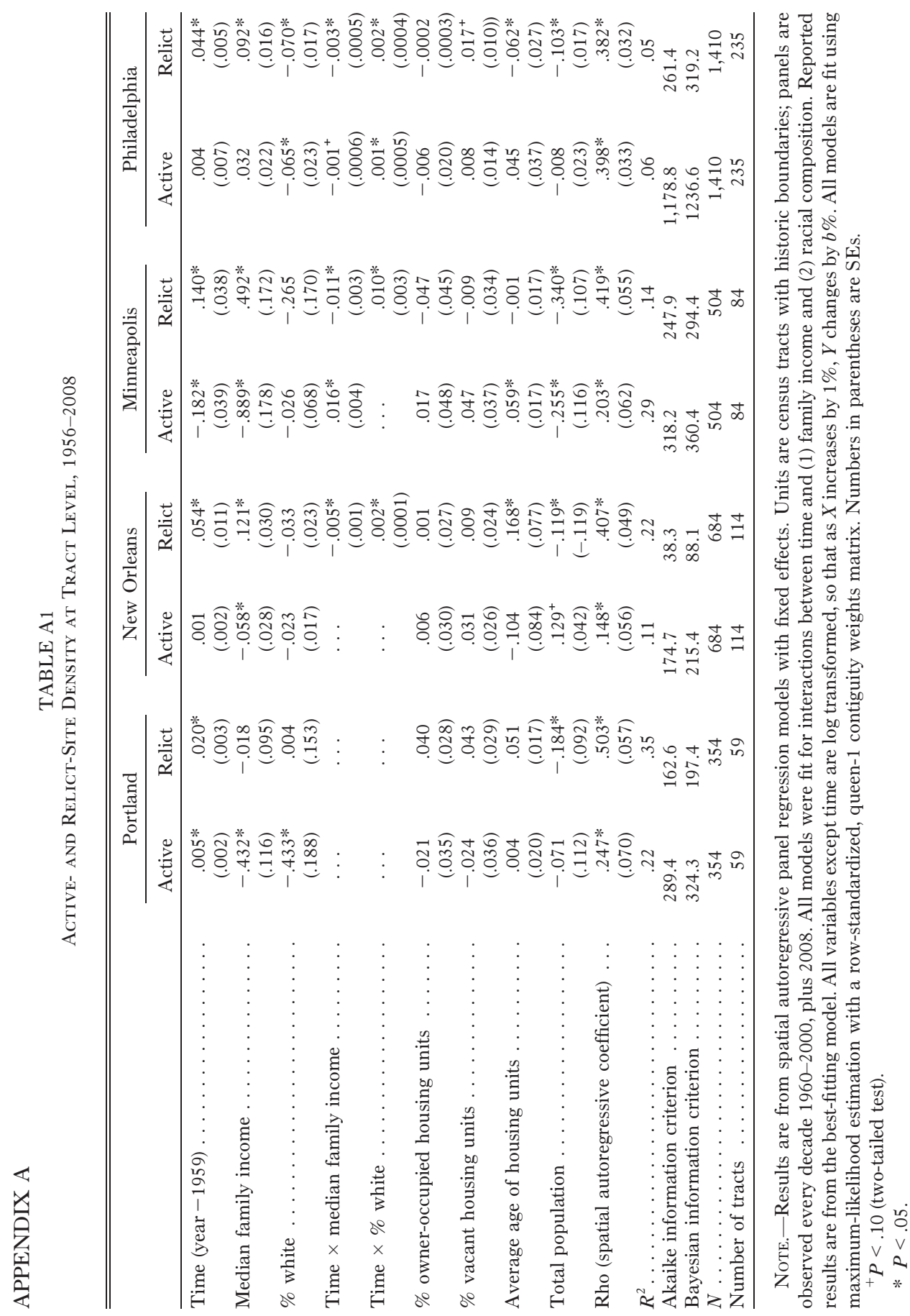

1772 
TABLE B1

Multinomial Regression Results Predicting Contemporary Site (Re)Use

\begin{tabular}{|c|c|c|c|c|}
\hline & \multicolumn{2}{|c|}{ Model 1} & \multicolumn{2}{|c|}{ Model 2} \\
\hline & $\begin{array}{c}\text { Still in } \\
\text { Hazardous Use }\end{array}$ & $\begin{array}{l}\text { Vacant or } \\
\text { Public Lot }\end{array}$ & $\begin{array}{c}\text { Still in } \\
\text { Hazardous Use }\end{array}$ & $\begin{array}{l}\text { Vacant or } \\
\text { Public Lot }\end{array}$ \\
\hline \multicolumn{5}{|l|}{$\begin{array}{l}\text { Hazardous facility } \\
\text { characteristics: }\end{array}$} \\
\hline \multicolumn{5}{|l|}{ Years in hazardous } \\
\hline operation ........ & $\begin{array}{l}.051^{*} \\
(.013)\end{array}$ & $\begin{array}{l}.000 \\
(.011)\end{array}$ & $\begin{array}{l}.031 * \\
(.014)\end{array}$ & $\begin{array}{l}.013 \\
(.013)\end{array}$ \\
\hline \multicolumn{5}{|l|}{ Never subject to federal } \\
\hline regulation $(1: 0) \ldots \ldots$ & $\begin{array}{c}-.545 \\
(.474)\end{array}$ & $\begin{array}{l}.887 * \\
(.439)\end{array}$ & & \\
\hline \multicolumn{5}{|l|}{ Exited pre-CERCLA } \\
\hline$(<1983)$ & $\ldots$ & $\cdots$ & $\begin{array}{c}-1.404 * \\
(.709)\end{array}$ & $\begin{array}{l}.708^{*} \\
(.338)\end{array}$ \\
\hline \multicolumn{5}{|l|}{ Never employed $10+$} \\
\hline workers $\ldots \ldots \ldots$ & $\ldots$ & $\cdots$ & $\begin{array}{l}-.935^{*} \\
(.760)\end{array}$ & $\begin{array}{l}.405 \\
(.322)\end{array}$ \\
\hline \multicolumn{5}{|l|}{ Tract characteristics } \\
\hline \multirow[t]{2}{*}{ Family income ... } & $\begin{array}{l}-.012 \\
(.015)\end{array}$ & $\begin{array}{l}.001 \\
(.005)\end{array}$ & $\begin{array}{r}-.007 \\
(.014)\end{array}$ & $\begin{array}{l}.001 \\
(.005)\end{array}$ \\
\hline & -.485 & -.606 & -.879 & -.583 \\
\hline$\%$ white & $(2.20)$ & $(.708)$ & $(2.12)$ & $(.707)$ \\
\hline \multirow[t]{2}{*}{$\%$ owner occupied } & .663 & -.009 & .645 & .020 \\
\hline & $(1.44)$ & $(.786)$ & $(1.40)$ & $(.802)$ \\
\hline \multirow[t]{2}{*}{$\%$ vacant } & 1.10 & 1.60 & 1.62 & 1.62 \\
\hline & $(3.786)$ & $(2.00)$ & $(3.42)$ & $(2.02)$ \\
\hline \multirow[t]{2}{*}{ Age of housing } & .009 & .005 & .009 & .003 \\
\hline & $(.014)$ & $(.010)$ & $(.014)$ & $(.010)$ \\
\hline \multirow[t]{2}{*}{ Total population } & $.535^{*}$ & .080 & $.529^{+}$ & .092 \\
\hline & $(.265)$ & $(.198)$ & $(.273)$ & $(.194)$ \\
\hline \multicolumn{5}{|l|}{ City: } \\
\hline Portland (reference) . . . & $\ldots$ & $\ldots$ & $\ldots$ & $\cdots$ \\
\hline \multirow[t]{2}{*}{ New Orleans ........ } & $-1.69^{+}$ & $.970^{+}$ & $-1.93 *$ & $1.02^{+}$ \\
\hline & $(.991)$ & $(.529)$ & $(.931)$ & $(.544)$ \\
\hline \multirow[t]{2}{*}{ Minneapolis . . . . . . . . } & $-3.12 *$ & .423 & $-3.40 *$ & .509 \\
\hline & $(1.41)$ & $(.723)$ & $(1.42)$ & $(.740)$ \\
\hline \multirow[t]{2}{*}{ Philadelphia } & $-2.09 *$ & $1.34 *$ & $-2.29 *$ & $1.31^{*}$ \\
\hline & $(.865)$ & $(.582)$ & $(.938)$ & $(.589)$ \\
\hline \multirow[t]{2}{*}{ Constant } & -24.41 & -12.36 & -23.96 & -9.28 \\
\hline & $(27.02)$ & $(19.21)$ & $(27.18)$ & (19.8) \\
\hline Log pseudo-likelihood . . . & \multicolumn{2}{|c|}{-236.6} & \multicolumn{2}{|c|}{-233.6} \\
\hline Wald $\mathrm{Chi}^{2}(d f) \ldots \ldots$ & \multicolumn{2}{|c|}{$54.59(22)$} & \multicolumn{2}{|c|}{$54.9(24)$} \\
\hline Pseudo $R^{2} \ldots \ldots \ldots \ldots$ & \multicolumn{2}{|c|}{.15} & \multicolumn{2}{|c|}{.16} \\
\hline
\end{tabular}

Note.-For these analyses, tract characteristics are measured using 2008 American Community Survey data with 2000 census tract boundaries. The indicator for being never subject to federal regulation is set to 1 if hazardous industry exited operation on-site before 1983 or never employed 10 or more workers; otherwise, the variable is set to $0 . N=390$. For models 1 and 2, the reference category for the dependent variable is active commercial, civic, or residential use - the modal type of reuse in each city. Numbers in parentheses are robust SEs.

${ }^{+} P<.10$ (two-tailed test).

$* P<.05$.

1773

This content downloaded from 128.042.238.003 on May 18, 2017 11:00:55 AM

All use subject to University of Chicago Press Terms and Conditions (http://www.journals.uchicago.edu/t-and-c). 
American Journal of Sociology

\section{REFERENCES}

Abbott, Andrew. 1999. Department and Discipline: Chicago Sociology at One Hundred. Chicago: University of Chicago Press.

Abbott, Carl. 1983. Portland: Planning, Politics, and Growth in a Twentieth-Century City. Lincoln: University of Nebraska Press.

Anderson, Nels. 1923. The Hobo. Chicago: University of Chicago Press.

Barles, Sabine. 2010. "Society, Energy and Materials: The Contribution of Urban Metabolism Studies to Sustainable Urban Development Issues." Journal of Environmental Planning and Management 53:439-55.

Bartomeus, Ignasi, John S. Ascher, Jason Gibbs, Bryan N. Danforth, et al. 2013. "Historical Changes in Northeastern US Bee Pollinators Related to Shared Ecological Traits." Proceedings of the National Academv of Sciences 110:4656-60.

Beck, Ulrich. 1992. Risk Society: Towards a New Modernity. London: Sage. . 2009. World at Risk. Malden, Mass.: Polity.

Brenner, Neil. 2013. "Theses on Urbanization." Public Culture 25:85-114.

Brulle, Robert J., and David N. Pellow. 2006. "Environmental Justice: Human Health and Environmental Inequalities." Annual Review of Public Health 27:103-24.

Bullard, Robert D., Glenn S. Johnson, and Angel O. Torres. 2000. Sprawl City: Race, Politics, and Planning in America. Washington, D.C.: Island Press.

Bunker, Stephen G. 1984. "Modes of Extraction, Unequal Exchange, and the Progressive Underdevelopment of an Extreme Periphery: The Brazilian Amazon, 16001980." American Journal of Sociology 89:1017-64.

Burgess, Ernest W. 1926. The Urban Community. Chicago: University of Chicago.

Burns, Lawton. 1980. "The Chicago School and the Study of Organization-Environment Relations." Journal of the Historv of the Behavioral Sciences 16:342-58.

Clements, Frederic E. 1916. Plant Succession. Washington, D.C.: Carnegie Institution of Washington.

Colten, Craig E. 1990. "Historical Hazards: The Geography of Relict Industrial Wastes." Professional Geographer 42:143-56.

. 2005. Unnatural Metropolis: Wresting New Orleans from Nature. Baton Rouge: Louisiana State University Press.

Colten, Craig E., and Peter N. Skinner. 1996. The Road to Love Canal: Managing Industrial Waste before EPA. Austin: University of Texas Press.

Cronon, William. 1991. Nature's Metropolis: Chicago and the Great West. New York: W.W. Norton.

Crowder, Kyle, and Liam Downey. 2010. "Inter-Neighborhood Migration, Race, and Environmental Hazards: Modeling Micro-level Processes of Environmental Inequality." American Journal of Sociologv 115:1110-49.

Davis, Mike. 1999. Ecology of Fear: Los Angeles and the Imagination of Disaster. New York: Vintage.

Dietrich, Gary N. 1981. "Ultimate Disposal of Hazardous Wastes." Pp. 1-12 in Toxic and Hazardous Waste Disposal, Volume 3, edited by Robert B. Pojasek. Ann Arbor, Mich.: Ann Arbor Science.

Downey, Liam. 2005. "The Unintended Significance of Race: Environmental Racial Inequality in Detroit." Social Forces 83:971-1008.

Elliott, James R., and Scott Frickel. 2013. "The Historical Nature of Cities: A Study of Urbanization and Hazardous Waste Accumulation." American Sociological Review 78:521-43.

Fitzgerald, Joan. 2010. Emerald Cities: Urban Sustainability and Economic Development. New York: Oxford University.

Fletcher, Thomas H. 2003. From Love Canal to Environmental Justice: The Politics of Hazardous Waste on the Canada-US Border. New York: Broadview. 
Foster, John Bellamy. 1999. "Marx's Theory of Metabolic Rift: Classical Foundations for Environmental Sociology.” American Journal of Sociology 105:366-405.

Freudenberg, William R. 1985. "Succession and Success: A New Look at an Old Concept.” Sociological Spectrum 5:269-89.

Frickel, Scott, and Michelle Edwards. 2014. "Untangling Ignorance in Environmental Risk Assessment." Pp. 215-33 in Powerless Science? The Making of the Toxic World in the 20th Century, edited by Nathalie Jas and Soraya Boudia. London: Berghahn Books.

Gaziano, Emanuel. 1996. "Ecological Metaphors as Scientific Boundary Work: Innovation and Authority in Interwar Sociology and Biology." American Journal of Sociology 101:874-907.

Grant, Don, Mary Nell Trautner, Liam Downey, and Lisa Thiebaud. 2010. "Bringing the Polluters Back in Environmental Inequality and the Organization of Chemical Production." American Sociological Revierw 75:479-504.

Gross, Mathias. 2004. "Human Geography and Ecological Sociology: The Unfolding of a Human Ecology, 1890 to 1930-and Beyond." Social Science Historv 28:575-605.

Hawkins, Keith. 1984. Environment and Enforcement: Regulation and the Social Definition of Pollution. Oxford: Clarendon Press.

Hawley, Amos. 1944. "Ecology and Human Ecology." Social Forces 22:398-405.

. 1986. Human Ecology. Chicago: University of Chicago Press.

Hays, Samuel P. 1987. Beauty, Health, and Permanence: Environmental Politics in the United States, 1955-1985. New York: Cambridge University Press.

Hess, David J. 2009. Localist Movements in a Global Economy: Sustainability, Justice, and Urban Development in the United States. Cambridge: MIT Press.

Hovey, Bradshaw. 1998. "Building the City, Structuring Change: Portland's Implicit Utopian Project." Utopian Studies 9:68-80.

Hoyt, Homer. 1933. One Hundred Years of Land Values in Chicago. New York: Arno. 1939. The Structure and Growth of Residential Neighborhoods in American Cities. Washington, D.C.: Federal Housing Administration.

Hurley, Andrew. 1995. Environmental Inequalities: Class, Race, and Industrial Pollution in Gary, Indiana, 1945-1980. Chapel Hill: University of North Carolina Press.

Kelman, Ari. 2006. A River and Its City: The Nature of Landscape in New Orleans. Los Angeles: University of California Press.

Krieg, Eric J. 1995. "A Socio-Historical Interpretation of Toxic Waste Sites: The Case of Greater Boston." American Journal of Economics and Sociology 54:1-14.

LeDuff, Charlie. 2013. Detroit: An American Autopsy. New York: Penguin Books.

Leigh, Nancy Green, and Sarah L. Coffin. 2000. "How Many Brownfields Are There? Building an Industrial Legacy Database.” Journal of Urban Technology 7:1-18.

Lejano, Raul P., and C. Scott Smith. 2006. "Incompatible Land Uses and the Topology of Cumulative Risk.” Environmental Management 37:230-46.

Lestel, L., M. Meybeck, and D. R. Thévenot. 2007. "Metal Contamination Budget at the River Basin Scale: An Original Flux-Flow Analysis (F2A) for the Seine River." Hvdrologv and Earth Sustem Sciences 11:1771-81.

Levine, Adeline Gordon. 1982. Love Canal: Science, Politics and People. Lexington, Mass.: D.C. Heath and Company.

Litt, Jill S., and Thomas A. Burke. 2002. "Uncovering the Historic Environmental Hazards of Urban Brownfields." Journal of Urban Health-Bulletin of the New York Academy of Medicine 79: 464-81.

Logan, John R., and Harvey L. Molotch. 1987. Urban Fortunes: The Political Economy of Place. Berkeley and Los Angeles: University of California Press.

Louisiana Department of Environmental Quality. 2011. www.deq.state.la.us/portal /tabid/269/ Default.aspx, accessed March 2011.

Maines, David R., Jeffrey C. Bridges, and Jeffrey T. Ulmer. 1996. "Mythic Facts and Park's Pragmatism." Sociological Ouarterly 37:5 21-49. 


\section{American Journal of Sociology}

Matthews, Fred H. 1977. Quest for an American Sociology: Robert E. Park and the Chicago School. Montreal: McGill-Queen's University Press.

McKenzie, Roderick D. 1925. "The Ecological Approach to the Study of the Human Community." Pp. 63-79 in The City, edited by Robert E. Park, Ernest W. Burgess, and R.D. McKenzie. Chicago: University of Chicago Press.

Melosi, Martin V. 2008. The Sanitary City: Environmental Services in Urban America from Colonial Times to the Present. Pittsburgh: University of Pittsburgh.

- 2010. "Humans, Cities, and Nature: How Do Cities Fit in the Material World?" Journal of Urban History 36:3-21.

Meyer, William E. 2009. "A City (Only Partly) on a Hill: Terrain and Land Use in PreTwentieth Century Boston.” Pp. 127-47 in Remaking Boston: An Environmental History of the City and its Surroundings, edited by Anthony N. Penna and Conrad Edick Wright. Pittsburgh: University of Pittsburgh.

Mill, John Stuart. 1906. A System of Logic, Ratiocinative and Inductive; Being a Connected View of the Principles of Evidence and the Methods of Scientific Investigation. London: Longmans Green.

Miller, T., M. Greenberg, K. Lowrie, H. Mayer, et al. 2000a. Brownfields Redevelopment as a Toolfor Smart Growth: Analysis of Nine New Jersey Municipalities (Report 12 for the Office of State Planning). New Brunswick, N.J.: National Center for Neighborhood and Brownfields Redevelopment, Rutgers University.

- 2000b. Addendum: Brownfields Redevelopment as a Tool for Smart Growth: Analysis of Twelve New Jersey Municipalities (Addendum to Report 12 for the Office of State Planning). New Brunswick, N.J.: National Center for Neighborhood and Brownfields Redevelopment, Rutgers University.

Mistry, Nisha, and Joan Byron. 2011. The Federal Role in Supporting Urban Manufacturing. Washington, D.C.: Brookings Institution.

Mitman, Gregg, Michelle Murphy, and Christopher Sellers, eds. 2004. Landscapes of Exposure: Knowledge and Illness in Modern Environments. Osiris vol.19.

Mohai, Paul, David Pellow, and J. Timmons Roberts. 2009. "Environmental Justice." Annual Review of Environment and Resources 34:405-30.

Molotch, Harvey. 1976. "The City as a Growth Machine." American Journal of Sociology 82:309-30.

Molotch, Harvey, William Freudenburg, and Krista E. Paulsen. 2000. "History Repeats Itself, but How? City Character, Urban Tradition, and the Accomplishment of Place." American Sociological Review 65:791-823.

Moore, Jason W. 2000. "Environmental Crisis and the Metabolic Rift in WorldHistorical Perspective." Organization and Environment 13:123-57.

. 2011. "Transcending the Metabolic Rift: A Theory of Crises in the Capitalist World-Ecology." Journal of Peasant Studies 38:1-46.

Noonan, Frank, and Charles A. Vidich. 1992. "Decision Analysis for Utilizing Hazardous Waste Site Assessments in Real Estate Acquisition.” Risk Analvsis 12:245-51.

Noyelle, Thierry J., and Thomas M. Stanback. 1984. The Economic Transformation of American Cities. Totowa, N.J.: Littlefield, Adams, Rowman \& Allanheld.

Oregon DEQ. 2011. http://www.deq.state.or.us/lq/ecsi/ecsi.htm, accessed March 2011.

Page, George W. 1997. Contaminated Sites and Environmental Cleanup: International Approaches to Prevention, Remediation, and Reuse. Waltham, Mass.: Academic Press.

Pais, Jeremy, and James R. Elliott. 2008. "Places as Recovery Machines: Vulnerability and Neighborhood Change after Major Hurricanes." Social Forces 86:1415-53.

Park, Robert. 1925. "The City." Pp. 1-46 in The City, edited by Robert E. Park, Ernest W. Burgess, and R.D. McKenzie. Chicago: University of Chicago Press. 171-79.

Pellow, David N. 2000. "Environmental Inequality Formation: Toward a Theory of Environmental Injustice.” American Behavioral Scientist 43:581-601. 


\section{Urbanization as Socioenvironmental Succession}

Peter, Camaren, and Mark Swilling. 2012. Sustainable, Resource Efficient CitiesMaking It Happen! Stockholm: United Nations Environment Programme.

Pickett, S. T. A., M. L. Cadenasso, and S. J. Meiners. 2008. "Ever Since Clements: From Succession to Vegetation Dynamics and Understanding to Intervention.” Applied Vegetation Science 12:9-21.

Quillian, Lincoln. 2012. "Segregation and Poverty Concentration: The Role of Three Segregations." American Sociological Review 77:354-79.

Reardon, Sean F., and Kendra Bischoff. 2011. "Income Inequality and Income Segregation." American Journal of Sociology 116:1092-153.

Rudel, Thomas K. 1989. Situations and Strategies in American Land-Use Planning. New York: Cambridge University.

2009. "Succession Theory: Reassessing a Neglected Meta-narrative about Environment and Development." Human Ecology Review 15:84-92.

2013. Defensive Environmentalists and the Dynamics of Global Reform. New York: Cambridge University Press.

Rudel, Thomas, J. Timmons Roberts, and JoAnn Carmin. 2011. "Political Economy of the Environment." Annual Review of Sociology 37:221-38.

Sadd, James L., Manuel Pastor, Rachel Morello-Frosch, Justin Scoggins, et al. 2011. "Playing It Safe: Assessing Cumulative Impact and Social Vulnerability through an Environmental Justice Screening Method in the South Coast Air Basin, California." International Journal of Environmental Research and Public Health 8:1441-59.

Saha, Robin, and Paul Mohai. 2005. "Historical Context and Hazardous Waste Facility Siting: Understanding Temporal Patterns in Michigan." Social Problems 52:618-48.

Stroud, Ellen. 1999. "Troubled Waters in Ecotopia: Environmental Racism in Portland, Oregon." Radical Historv Review 74:65-95.

Sveden, J., and A. Jonsson. 2001. "Urban Metabolism of Mercury Turnover, Emissions and Stock in Stockholm 1795-1995." Water, Air, and Soil Pollution: Focus 1 (3-4): 179-96.

Tarr, Joel A. 2002. "The Metabolism of the Industrial City." Journal of Urban Historv 28: $511-45$.

U.S. Congress, House of Representatives. 1979. Waste Disposal Survey: Report. 96th Congress, 1st Session. Committee Print 96-IFC 33, 1979, x, and Appendix E.

U.S. Department of Labor. 2013. Standard Industrial Classifications. http://www.osha .gov/pls/imis/sic_manual.html. Accessed June 17, 2013.

U.S. Environmental Protection Agency. 2011. 2010 TRI National Analysis. http://www .epa.gov/tri/. Accessed May 29, 2013.

Wernstedt, Kris, Lauren Heberle, Anna Alberini, and Peter Meyer. 2004. "The Brownfields Phenomenon: Much Ado about Something or the Timing of the Shrewd?" Discussion Paper 04-46. Washington, D.C.: Resources for the Future. http://www.rff.org /rff/documents/rff-dp-04-46.pdf .

Wilson, Kenneth L., and Alejandro Portes. 1980. "Immigrant Enclaves: An Analysis of the Labor Market Experiences of Cubans in Miami." American Journal of Sociologv 86:295-319.

Wirth, Louis. 1928. The Ghetto. Chicago: University of Chicago Press.

Woodruff, Tracey J., Jennifer D. Parker, Lyndsey A. Darrow, Rémy Slama, et al. 2009. "Methodological Issues in Studies of Air Pollution and Reproductive Health." Environmental Research 109:311-20.

Zorbaugh, Harvey. 1926. "The Natural Areas of the City." Pp. 217-29 in The Urban Community edited by Ernest W. Burgess. Chicago: University of Chicago Press.

- 1929. The Gold Coast and the Slum: A Sociological Study of Chicago's Near North Side. Chicago: University of Chicago Press.

Zukin, Sharon. 1987. "Gentrification: Culture and Capital in the Urban Core." Annual Review of Sociology 13:129-47. 